\title{
Cytoprotective and Cytotoxic Effects of Rice Bran Extracts in Rat H9c2(2-1) Cardiomyocytes
}

\author{
Xian Wen Tan, ${ }^{1,2}$ Mrinal Bhave, ${ }^{3}$ Alan Yean Yip Fong, ${ }^{4,5}$ Eiji Matsuura, ${ }^{6,7}$ \\ Kazuko Kobayashi, ${ }^{6,7}$ Lian Hua Shen, ${ }^{6,7}$ and Siaw San Hwang ${ }^{1,2}$ \\ ${ }^{1}$ Faculty of Engineering, Computing and Science, Swinburne University of Technology Sarawak Campus, Jalan Simpang Tiga, \\ 93350 Kuching, Sarawak, Malaysia \\ ${ }^{2}$ Swinburne Sarawak Research Centre for Sustainable Technologies, Swinburne University of Technology Sarawak Campus, \\ Jalan Simpang Tiga, 93350 Kuching, Sarawak, Malaysia \\ ${ }^{3}$ Faculty of Science, Engineering and Technology, Swinburne University of Technology, Hawthorn, Melbourne, VIC 3122, Australia \\ ${ }^{4}$ Sarawak General Hospital Heart Centre, 94300 Kota Samarahan, Sarawak, Malaysia \\ ${ }^{5}$ Clinical Research Centre, Sarawak General Hospital, Jalan Hospital, 93586 Kuching, Sarawak, Malaysia \\ ${ }^{6}$ Collaborative Research Center (OMIC), Okayama University Graduate School of Medicine, Dentistry, and Pharmaceutical Sciences, \\ Okayama 700-8558, Japan \\ ${ }^{7}$ Department of Cell Chemistry, Okayama University Graduate School of Medicine, Dentistry, and Pharmaceutical Sciences, \\ Okayama 700-8558, Japan
}

Correspondence should be addressed to Siaw San Hwang; shwang@swinburne.edu.my

Received 17 December 2015; Revised 7 March 2016; Accepted 29 March 2016

Academic Editor: Silvana Hrelia

Copyright (C) 2016 Xian Wen Tan et al. This is an open access article distributed under the Creative Commons Attribution License, which permits unrestricted use, distribution, and reproduction in any medium, provided the original work is properly cited.

\begin{abstract}
This study was aimed at preliminarily assessing the cytoprotective and antioxidative effects of rice bran extracts (RBEs) from a Sarawak local rice variety (local name: "BJLN") and a commercial rice variety, "MR219," on oxidative stress in rat H9c2(21) cardiomyocytes. The cardiomyocytes were incubated with different concentrations of RBE and hydrogen peroxide $\left(\mathrm{H}_{2} \mathrm{O}_{2}\right)$, respectively, to identify their respective $\mathrm{IC}_{50}$ values and safe dose ranges. Two nonlethal and close-to-IC $\mathrm{I}_{50}$ doses of $\mathrm{RBE}$ were selected to evaluate their respective effects on $\mathrm{H}_{2} \mathrm{O}_{2}$ induced oxidative stress in cardiomyocytes. Both RBEs showed dosedependent cytotoxicity effects on cardiomyocytes. $\mathrm{H}_{2} \mathrm{O}_{2}$ induction of cardiomyocytes pretreated with RBE further revealed the dose-dependent cytoprotective and antioxidative effects of RBE via an increase in $\mathrm{IC}_{50}$ values of $\mathrm{H}_{2} \mathrm{O}_{2}$. Preliminary analyses of induction effects of $\mathrm{RBE}$ and $\mathrm{H}_{2} \mathrm{O}_{2}$ on cellular antioxidant enzyme, catalase (CAT), also revealed their potential in regulating these activities and expression profile of related gene on oxidative stress in cardiomyocytes. Pretreated cardiomyocytes significantly upregulated the enzymatic activity and expression level of CAT under the exposure of $\mathrm{H}_{2} \mathrm{O}_{2}$ induced oxidative stress. This preliminary study has demonstrated the potential antioxidant effects of RBE in alleviating $\mathrm{H}_{2} \mathrm{O}_{2}$-mediated oxidative injuries via upregulation in enzymatic activities and expression levels of CAT.
\end{abstract}

\section{Introduction}

Research on plant-derived natural antioxidants has become one of the emerging fields of study in recent years [1]. Phytochemicals are natural antioxidants, comprised of phenolic or polyphenolic compounds such as polyphenols, flavonoids, anthocyanins, vitamins, and/or resveratrol, which are commonly found in fruits, vegetables, and nuts [2]. It has been demonstrated that frequent dietary intake of antioxidant-rich food is commonly linked with low incidence of oxidative stress associated diseases. These naturally occurring bioactive constituents provide a defense system to the body by eliminating free radicals and protecting the body against oxidative injury [3]. Studies on natural antioxidants have shown positive health effects towards cardioprotection, anti-inflammation, anti-infection, liver protection, antidiabetic, antiobesity, and antineurodegenerative processes [49]. These health benefits are proposed to be attributed to 
the synergistic antioxidant protective effects of different phytochemicals [10].

Natural antioxidants have been proven to quench free radicals effectively, improve the antioxidant status of cells, and provide protection against cellular oxidative injuries [11]. Interactions between oxidants and antioxidants control various crucial cellular pathways and metabolism; the simple "oxidant-antioxidant imbalance" theory has now grown to be incorporated into the progression of various chronic diseases. Hence, the rationale for strategies utilizing exogenous natural antioxidants as therapeutic intervention to attenuate cardiac injury through inhibition of inadvertent cellular oxidative damage or signaling pathways may have important implications for both the prevention and treatment of these diseases [2].

Rice is a staple food and remains the utmost important agricultural commodity in many Asian countries [12]. It provides the main source of calories and nourishment for the majority of the Asian population's nutritional requirement [13]. In addition, rice continues to play a significant role in sustaining global food security systems and establishing a continual capacity to feed the increasing world population [14]. The whole rice grain is known for containing rich contents of vitamins, lipids, minerals, proteins, fibres, and numerous antioxidants [15] which may aid in disease control [16]. Major composition of these bioactive compounds is found in the bran of rice grain. Several research works involving animal models have been focusing on the health attributes of rice bran in the prevention and treatment of chronic diseases. The outcomes from these studies revealed positive correlation between the consumption of rice bran and risk reductions in chronic diseases such as cardiovascular disease [17-19], cancers [20, 21], type 2 diabetes [22], hypertension, and hyperlipidaemia [23]. Through the emerging knowledge of rice bran in health and wellness, its consumption has begun to gain popularity in recent years [24]. The current research trend in rice bran revolves around its innovation in the food system that aims to alleviate issues of malnutrition and chronic diseases. In addition, emphasis is also put on the genetic, geographic, and nutritional diversities of different rice varieties and their associated health attributes [25]. By addressing all these research statements, it will provide global health prospects for proper and innovative utilization of rice bran in the management of chronic diseases. Hence in the present study, we determined the cytoprotection and the antioxidant properties of rice bran extract derived from a Sarawak local rice variety ("BJLN") and a commercial rice variety (“MR219").

\section{Materials and Methods}

2.1. Chemicals and Materials. Analytical grade methanol (MetOH) (EMSURE ${ }^{\circledR}$ ) was purchased from Merck (Darmstadt, Germany). Absolute ethanol (EtOH) was purchased from Fisher Scientific (Malaysia). H9c2(2-1) cardiomyocytes of Rattus norvegicus rat (ATCC ${ }^{\circledR}$ CRL-1446 ${ }^{\mathrm{TM}}$ ) were purchased from ATCC. CellTiter $96{ }^{\circledR}$ Aqueous Non-Radioactive Cell Proliferation Assay Kit was purchased from Promega; Dulbecco's Modified Eagle Medium (DMEM) and phosphate buffer saline (PBS) were purchased from Gibco ${ }^{\circledR}$. Fetal Bovine Serum (FBS), penicillin-streptomycin (10,000 units), 0.25\% trypsin-EDTA, trypan blue, and dimethyl sulfoxide (DMSO) were purchased from Sigma Aldrich. AxyPrep Multisource Total RNA Miniprep Kit was purchased from Axygen. QuantiFast SYBR ${ }^{\circledR}$ Green RT-PCR Kit was purchased from Qiagen. Catalase Assay Kit was purchased from Cayman Chemical.

\subsection{Methodology}

2.2.1. Preparation of Rice Bran Extracts (RBEs). Preparation of RBE was carried out at a sample-mass-to-solvent ratio of 1:10 (gram to millilitres), using $3 \mathrm{~g}$ of rice bran and $30 \mathrm{~mL}$ of analytical grade methanol. The mixture was stirred continuously on a stirring hot plate (Stirring Hot Plate HS0707V2, Favorit) for 30 minutes, at room temperature. After 30 minutes, the RBEs were centrifuged (Centrifuge 5702, Eppendorf) for 10 minutes at 1,000 RPM. The supernatants were collected and extraction of the residual bran samples was repeated twice more and all the supernatants were combined.

The solvents in the collected extracts were then evaporated using rotary evaporator at $35^{\circ} \mathrm{C}$ (RE300, Yamato) and further concentrated using vacuum concentrator (7810037, Labconco) until they were fully lyophilized. The lyophilized extracts were then weighed and kept in a $-22^{\circ} \mathrm{C}$ freezer until further use. The lyophilized extract samples were dispersed in absolute ethanol to prepare crude extracts, each with a known mass concentration. These prepared stocks were then used to prepare a series of diluted ( $2 \mathrm{x}$ dilution) samples.

2.3. Cell Culture. H9c2(2-1) cardiomyocytes of Rattus norvegicus rat were used as the mammalian cell culture model for the antioxidant assay. The cells were cultivated in DMEM media supplemented with $10 \%$ FBS and 100 units $/ \mathrm{mL}$ of penicillin-streptomycin (final concentration). Cells were incubated at $37^{\circ} \mathrm{C}$ and $5 \% \mathrm{CO}_{2}$. Subcultivation of cells was performed when cells achieved $70 \%-80 \%$ confluency. Cells in passages numbers 20-25 were used in all experiments and cells $\left(7.5 \times 10^{3}\right.$ cells/per well $)$ were seeded on a 96 -well microplate for different experiments.

2.4. Cell Cytotoxicity Assay. Cell toxicity effects of selected $\mathrm{RBE}$ and $\mathrm{H}_{2} \mathrm{O}_{2}$ were studied by using a 3-(4,5-dimethylthiazol-2-yl)-5-(3-carboxymethoxyphenyl)-2-(4-sulfophenyl)-

2H tetrazolium- (MTS-) based assay kit (CellTiter 96 Aqueous Non-Radioactive Cell Proliferation Assay Kit, Promega). Approximately $7.5 \times 10^{3}$ cells were plated onto each well of a 96-well microplate and preincubated for 24 hours before the cells were further treated with RBE.

2.4.1. Cell Cytotoxicity Study of RBE. Different concentrations (approximately $6.25 \mu \mathrm{g} / \mathrm{mL}$ to $500 \mu \mathrm{g} / \mathrm{mL}$ ) of selected $\mathrm{RBE}$ were prepared by serially diluting the prepared stocks in twofold dilutions with serum-free DMEM. The final concentration of ethanol content in each sample was kept below $1 \%(\mathrm{v} / \mathrm{v})$, and media containing ethanol $(1 \% \mathrm{v} / \mathrm{v})$ were used as negative control in the assays. Three separate sets of experiments were set up to study the time-dependent 
cytotoxicity effects of RBE treated cells over the duration of 24,48 , and 72 hours, respectively. Cell viability was determined via the MTS assay kit (CellTiter 96 Aqueous NonRadioactive Cell Proliferation Assay Kit, Promega). Briefly, after the incubation period, cells were washed with PBS buffer and later replenished with fresh serum-free DMEM. MTS reagent was then added to each well and the microplate was incubated for 4 hours before the absorbance was measured at $490 \mathrm{~nm}$ through a microplate reader (Synergy HT, Biotek). Cell cytotoxicity effects of rice bran extracts were determined by identifying the dosage decreasing the cell viability by $50 \%$ of the initial population.

2.4.2. Cell Cytotoxicity Study of Hydrogen Peroxide $\left(\mathrm{H}_{2} \mathrm{O}_{2}\right)$. Different concentrations (approximately $15 \mu \mathrm{M}$ to $1000 \mu \mathrm{M}$ ) of $\mathrm{H}_{2} \mathrm{O}_{2}$ were prepared by serially diluting the prepared stock $(1000 \mu \mathrm{M})$ in twofold dilutions with PBS buffer. The range of concentrations was prepared to identify the dose-dependent cell cytotoxicity effects of $\mathrm{H}_{2} \mathrm{O}_{2}$. Standardisation of $\mathrm{H}_{2} \mathrm{O}_{2}$ was performed spectrophotometrically by measuring the absorbance of prepared samples at $240 \mathrm{~nm}$, and a molar extinction coefficient of $43.6 \mathrm{M}^{-1} \mathrm{~cm}^{-1}$ was used to calculate the actual concentration of $\mathrm{H}_{2} \mathrm{O}_{2}$ prepared. PBS buffer was used as negative control in the assay. $\mathrm{H}_{2} \mathrm{O}_{2}$ treated cells were incubated for 24 hours and cell viability was determined via the MTS assay kit (CellTiter 96 Aqueous Non-Radioactive Cell Proliferation Assay Kit, Promega). Briefly, after the incubation period, media were discarded and cells were washed and replaced with fresh serum-free DMEM. MTS reagent was then added to each well and the microplate was incubated for 4 hours before the absorbance was measured as above.

2.5. Cytoprotective Effects of RBE on Oxidative Stress Induced Cells. H9c2(2-1) cells were seeded and incubated at $37^{\circ} \mathrm{C}$ and $5 \% \mathrm{CO}_{2}$ for 24 hours before they were treated with $\mathrm{RBE}$. The cells were treated with specific concentrations of the selected RBE and were incubated for 24 hours. After 24 hours of incubation, growth media were replaced and oxidative stress was induced by treating the cells with different concentrations (approximately $62.5 \mu \mathrm{M}$ to $1000 \mu \mathrm{M}$ ) of $\mathrm{H}_{2} \mathrm{O}_{2}$. The treated cells were incubated for another 24 hours before the cell viability was determined via MTS assay kit (CellTiter 96 Aqueous Non-Radioactive Cell Proliferation Assay Kit, Promega). MTS reagent was then added to each well and the microplate was incubated for 4 hours before the absorbance was measured at $490 \mathrm{~nm}$ as above.

2.6. Endogenous Antioxidant Enzyme Activity Study. Catalase (CAT) was the targeted endogenous antioxidant enzyme in this experiment. The activity of CAT was studied by using commercially available ELISA kit. Samples were prepared as per protocols stated in the kits' manual. Briefly, cells were detached by using rubber policeman and collected in ice cold PBS buffer ( $\mathrm{pH}$ 7.4). Cell lysis was performed via physical disruption by sonicating the cells in ultrasonic water bath for 2 minutes. The CAT activity was examined via Catalase Assay Kit (Cayman Chemical). The absorbances of reaction mixtures were measured at respective wavelength defined for the assay kit.

2.7. Endogenous Antioxidant Enzyme Gene Expression Study. Catalase (CAT) (catalase, Cat (Gene ID: 24248)) was the targeted endogenous antioxidant enzyme in this experiment. The effects of $\mathrm{RBE}$ and $\mathrm{H}_{2} \mathrm{O}_{2}$ inductions on the gene expression of targeted endogenous antioxidant enzyme, CAT, were assessed through quantitative Real Time Polymerase Chain Reaction (qRT-PCR) approach. H9c2(2-1) cells were seeded and incubated at $37^{\circ} \mathrm{C}$ and $5 \% \mathrm{CO}_{2}$ on 6 -well plates for 24 hours before they were treated with $\mathrm{RBE}$ and $\mathrm{H}_{2} \mathrm{O}_{2}$, respectively.

2.7.1. Total RNA Extraction. Extraction of RNA from H9c2(21) cardiomyocytes was performed through AxyPrep Multisource Total RNA Miniprep Kit (Axygen Biosciences). Prior to RNA extraction, supernatants were discarded and cells were washed twice with ice cold PBS buffer ( $\mathrm{pH}$ 7.4). Then, the extraction of RNA from cells was performed as described in the kit protocol. RNase-free water was used to elute the purified total RNA. RNA samples were kept on ice when in use or stored at $-80^{\circ} \mathrm{C}$ until further use.

2.7.2. Nucleic Acid Quantitation and Qualification. The concentration and purity of extracted RNA were assessed spectrophotometrically through a microplate reader (Synergy HT, Biotek) by using Take 3 Micro-Volume Plates. The preset settings for nucleic acid quantitation and qualification were selected, and the absorbances of samples were measured at the wavelengths of $230 \mathrm{~nm}, 260 \mathrm{~nm}$, and $280 \mathrm{~nm}$, with a background check at $320 \mathrm{~nm}$ (background check). RNasefree water was used as blank reagent. The absorbance ratios of 260/280 and 260/230 were used to determine the purity of RNA samples. The acceptable absorbance ratio for $260 / 280$ as pure RNA is $\geq 2.0$ while that for $260 / 230$ is 2.0 to 2.2 ref.

2.7.3. Relative Quantitation of Gene Expression. Gene expression studies of targeted endogenous cellular antioxidant enzymes were performed through qRT-PCR approach. A one-step qRT-PCR kit (QuantiFast SYBR Green RT-PCR Kit, Qiagen) was used to quantify the RNA targets. A total of $20 \mathrm{ng}$ of RNA sample (final amount per reaction tube $=2 \mathrm{ng}$ ) was mixed with reagent kits and oligonucleotide primer sets as per manufacturer's instructions. The primers used in this experiment were as follows:

Catalase (CAT)

(Gene ID: 24248)

Species: Rattus norvegicus

Forward Primer: $5^{\prime}$-CGCCTGTGTGAGAACATTGC-3' Reverse Primer: 5'-TAGTCAGGGTGGACGTCAGT-3 ${ }^{\prime}$

Glyceraldehyde 3-phosphate dehydrogenase (GAPDH)

(Gene ID: 24383) 


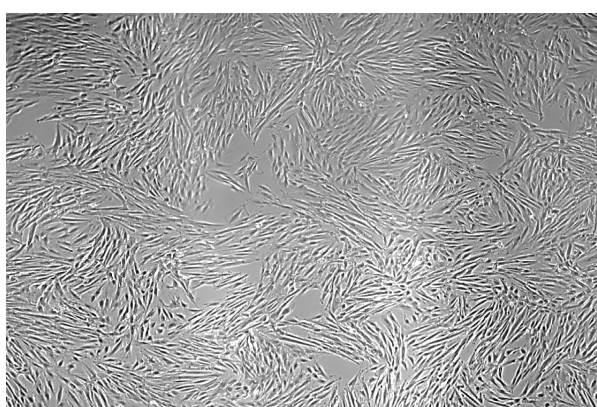

(a)

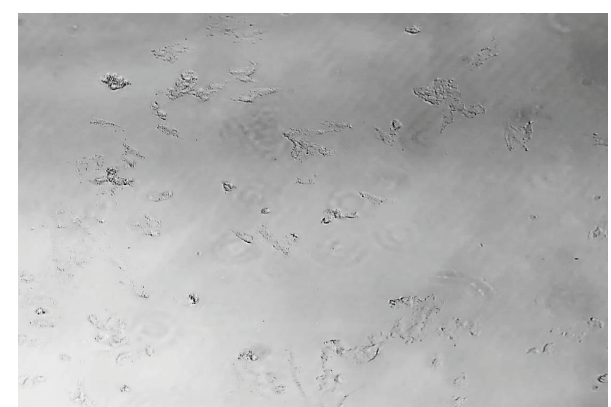

(b)

FIGURE 1: Changes in cellular morphology of H9c2(2-1) cardiomyocytes resulting from treatment with RBE. (a) Untreated cells (negative control, with 1\% EtOH); (b) cells treated with BJLN RBE (500 $\mu \mathrm{g} / \mathrm{mL})$ (Nikon Eclipse Ti-S; mag 40x).

\section{Species: Rattus norvegicus}

\section{Forward Primer: \\ $5^{\prime}$-CAG GGC TGC CTT CTC TTG TG- $3^{\prime}$ \\ Reverse Primer: \\ 5'-CTT GCC GTG GGT AGA GTC AT-3'}

Amplification reactions of RNA targets were performed via Rotor-Gene Q 2plex HRM Platform (Qiagen). Settings for reaction cycles were configured as specified in the kit manual. All reactions were normalized to mRNA expression of the housekeeping gene, GAPDH for Rattus norvegicus. All samples were prepared in triplicate and relative gene expression levels of RNA targets were normalized to that of negative control cells.

2.8. Statistical Analysis. All results data are presented as mean and standard deviation of three consecutive technical repetitions on the statistical tool; GraphPad Prism (GraphPad Software, Inc., USA) was used to analyse the data via one-way analysis of variance (ANOVA) and Student's $t$-test. Statistical significance and confidence level of data are set at $P \leq 0.05$.

\section{Results and Discussion}

3.1. Assessment of Cell Cytotoxicity Effects of Rice Bran Extracts (RBEs). Figure 1 shows the microscopy images (magnification: 40x) of untreated (negative control) and treated $\mathrm{H} 9 \mathrm{c} 2(2-$ 1) cells. The $\mathrm{H} 9 \mathrm{c} 2(2-1)$ cells were treated with $500 \mu \mathrm{g} / \mathrm{mL}$ RBE of BJLN in the cell culture medium, while the negative control cells were treated with $1 \%(\mathrm{v} / \mathrm{v}) \mathrm{EtOH}$. The $1 \%(\mathrm{v} / \mathrm{v})$ $\mathrm{EtOH}$ did not induce any cytotoxic effect (Figure 1(a)) on the cells. The cells were found to be thin and elongated and appear to be multinucleated (having multiple nuclei in a cell), as expected for muscle cells. In contrast, H9c2(2-1) cells treated with $500 \mu \mathrm{g} / \mathrm{mL} \mathrm{RBE}$ of BJLN induced distorted cell morphologies, with disintegration of cell membrane and nuclei (Figure 1(b)), and cellular debris spreading across the surface of the cell culture flask. The observations indicate that the RBE of BJLN is cytotoxic to H9c2(2-1) cells at dosage of $500 \mu \mathrm{g} / \mathrm{mL}$ with cell viability significantly dropped to only $18.58 \%(P<0.01)$ as compared to negative control.
H9c2(2-1) cardiomyocytes were induced with different concentrations of RBE $(6.25 \mu \mathrm{g} / \mathrm{mL}-1000 \mu \mathrm{g} / \mathrm{mL})$ over 24,48 , and 72 hours of incubation to identify their respective safe dose range. Cell toxicities of selected RBE were examined via MTS-based assay kit, which measures the metabolic rate of mitochondrial activities through conversion of MTS to formazan by viable cells [26]. Data are presented in terms of relative cell viability versus log of extract dosage (Figure 2 ).

Dose-dependent cytotoxicity was observed in cells treated with RBE of BJLN and MR219. For RBE of BJLN, extract concentrations beyond $75 \mu \mathrm{g} / \mathrm{mL}$ induced cell death, with cell viabilities dropping below $32 \%$ (Table 1). Cell viabilities dropped below 20\% after 48 and 72 hours. However, viabilities of $\mathrm{H} 9 \mathrm{c} 2(2-1)$ cells treated with BJLN RBE in the range of approximately $6.25 \mu \mathrm{g} / \mathrm{mL}$ to $50 \mu \mathrm{g} / \mathrm{mL}$ were $>70 \%$ throughout the three incubation times. In accordance with the International Organization for Standardization (ISO), ISO 10993-5, cellular response with cell viability that falls within $70 \%$ and above is considered noncytotoxic [27]. With regard to the obtained result, it indicated that the safe working concentration range of this extract is up to $50 \mu \mathrm{g} / \mathrm{mL}$. The half maximal inhibitory concentration $\left(\mathrm{IC}_{50}\right)$ of RBE refers to the concentration of RBE required for the inhibition of cell viability by $50 \%$ in comparison to negative control cells [28]. Based on the results (Table 2), the $\mathrm{IC}_{50}$ values of RBE of BJLN were in the range of 61.67 to $64.57 \mu \mathrm{g} / \mathrm{mL}$ over 24,48 , and 72 hours of incubation time.

For RBE of MR219, concentrations $>250 \mu \mathrm{g} / \mathrm{mL}$ induced critical cell death, with $\mathrm{H} 9 \mathrm{c} 2(2-1)$ cell viabilities dropping below 13\% (Table 1). Cell viabilities further dropped below $12 \%$ with $500 \mu \mathrm{g} / \mathrm{mL}$ after 24,48 , and 72 hours of incubation. Contrarily, viabilities of cells treated with MR219 extract in the range of 6.25 to $75 \mu \mathrm{g} / \mathrm{mL}$ were $>70 \%$ throughout the three different incubation periods. Therefore, the safe concentration range of MR219 extract appears to be 6.25$75 \mu \mathrm{g} / \mathrm{mL}$ (Table 1). Based on the results, the $\mathrm{IC}_{50}$ values of MR219 RBE were in the range of 95.44 to $111.50 \mu \mathrm{g} / \mathrm{mL}$ over the three different incubation periods (Table 2).

The results showed the dose-dependent cytotoxic effects of BJLN and MR219 extracts on H9c2(2-1) cardiomyocytes. In general, cell viabilities dropped below $20 \%$ when high doses $(>250 \mu \mathrm{g} / \mathrm{mL})$ of RBE were used. Induction of cells with RBE 


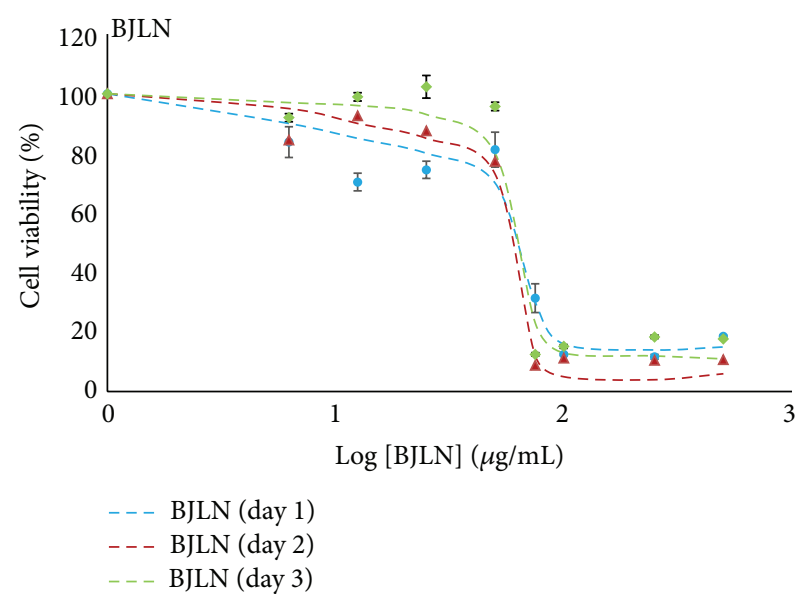

(a)

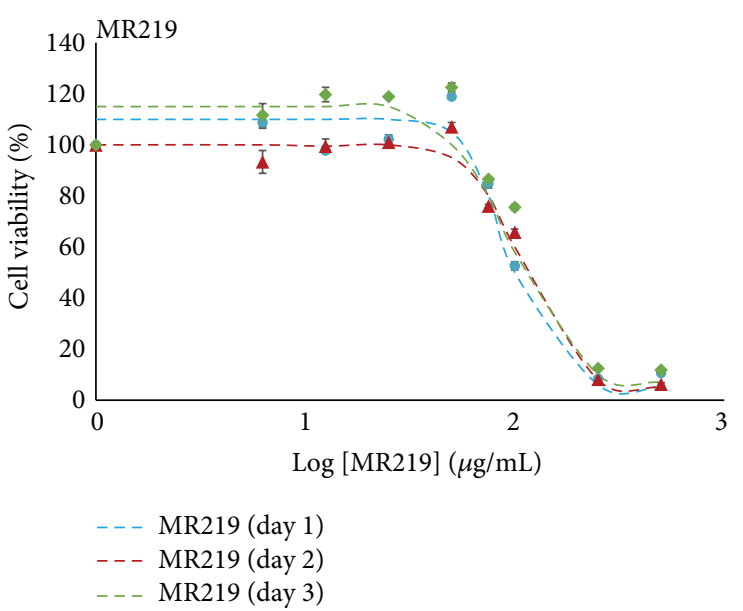

(b)

FIGURE 2: Cell viability of H9c2(2-1) cardiomyocytes treated with RBE. The H9c2(2-1) cardiomyocytes were treated with different concentrations (approximately $6.25 \mu \mathrm{g} / \mathrm{mL}$ to $500 \mu \mathrm{g} / \mathrm{mL}$ ) of BJLN and MR219 RBE over 24 (blue circle), 48 (red triangle), and 72 (green diamond) hours of incubation time, respectively. Best fit curves drawn by using Excel.

TABLE 1: Cell viability of H9c2(2-1) after induction with RBE of BJLN and MR219.

\begin{tabular}{|c|c|c|c|c|c|c|c|}
\hline \multirow{3}{*}{$\begin{array}{l}\log \\
(\text { dose })\end{array}$} & \multirow{3}{*}{ Dose $(\mu \mathrm{g} / \mathrm{mL})$} & \multicolumn{6}{|c|}{ Cell viability (\%) } \\
\hline & & \multicolumn{3}{|c|}{ BJLN } & \multicolumn{3}{|c|}{ MR219 } \\
\hline & & $\begin{array}{c}\text { Day } 1 \\
\text { (24 hours) }\end{array}$ & $\begin{array}{c}\text { Day } 2 \\
\text { (48 hours) }\end{array}$ & $\begin{array}{c}\text { Day } 3 \\
\text { (72 hours) }\end{array}$ & $\begin{array}{c}\text { Day } 1 \\
\text { (24 hours) }\end{array}$ & $\begin{array}{c}\text { Day } 2 \\
\text { (48 hours) }\end{array}$ & $\begin{array}{c}\text { Day } 3 \\
\text { (72 hours) }\end{array}$ \\
\hline 0.80 & 6.25 & $83.76 \pm 5.18$ & $84.47 \pm 1.45^{*}$ & $91.96 \pm 2.70^{*}$ & $108.88 \pm 4.76$ & $93.34 \pm 8.97$ & $111.70 \pm 5.63$ \\
\hline 1.10 & 12.5 & $70.33 \pm 5.95^{*}$ & $92.55 \pm 2.38^{*}$ & $98.93 \pm 2.75$ & $97.78 \pm 1.21$ & $99.48 \pm 5.67$ & $119.73 \pm 5.63^{*}$ \\
\hline 1.40 & 25 & $74.42 \pm 5.79^{*}$ & $87.51 \pm 5.77$ & $102.32 \pm 7.60$ & $102.22 \pm 3.44$ & $101.05 \pm 1.44$ & $118.93 \pm 1.61^{*}$ \\
\hline 1.70 & 50 & $81.19 \pm 5.86^{*}$ & $77.23 \pm 3.02$ & $95.71 \pm 2.75$ & $118.93 \pm 1.42^{*}$ & $107.03 \pm 3.41$ & $122.50 \pm 3.65^{*}$ \\
\hline 1.88 & 75 & $31.37 \pm 4.83^{*}$ & $8.81 \pm 0.00^{*}$ & $12.50 \pm 1.12^{*}$ & $84.99 \pm 3.68^{*}$ & $76.08 \pm 1.27^{*}$ & $86.61 \pm 2.64^{*}$ \\
\hline 2.00 & 100 & $12.44 \pm 0.74^{*}$ & $11.23 \pm 0.48^{*}$ & $15.14 \pm 1.29^{*}$ & $52.57 \pm 3.21^{*}$ & $65.79 \pm 2.38^{*}$ & $75.54 \pm 3.21^{*}$ \\
\hline 2.40 & 250 & $11.68 \pm 1.61^{*}$ & $10.49 \pm 0.66^{*}$ & $18.33 \pm 1.09^{*}$ & $8.41 \pm 0.61^{*}$ & $8.18 \pm 0.55^{*}$ & $12.50 \pm 1.12^{*}$ \\
\hline 2.70 & 500 & $18.57 \pm 0.61^{*}$ & $10.70 \pm 0.94^{*}$ & $17.68 \pm 0.00^{*}$ & $10.63 \pm 1.13^{*}$ & $6.30 \pm 1.09^{*}$ & $11.79 \pm 1.86^{*}$ \\
\hline
\end{tabular}

Data represented as mean \pm standard deviation of three technical replicates $(n=3) .{ }^{*}$ Significant difference at $P \leq 0.05$ as compared to negative control.

TABLE 2: The inhibitory concentration $\left(\mathrm{IC}_{50}\right.$ ) of RBE of BJLN and MR219. Data presented as mean \pm standard deviation of three technical replicates $(n=3)$.

\begin{tabular}{lcccc}
\hline & \multicolumn{2}{c}{ BJLN } & \multicolumn{2}{c}{ MR219 } \\
& $\begin{array}{c}\log (\text { dose }) \\
(\mu \mathrm{g} / \mathrm{mL})\end{array}$ & $\begin{array}{c}\text { Dose } \\
(\mu \mathrm{g} / \mathrm{mL})\end{array}$ & $\begin{array}{c}\log (\text { dose }) \\
(\mu \mathrm{g} / \mathrm{mL})\end{array}$ & $\begin{array}{c}\text { Dose } \\
(\mu \mathrm{g} / \mathrm{mL})\end{array}$ \\
\hline $\begin{array}{l}\text { Day 1 } \\
(24 \text { hours })\end{array}$ & $1.81 \pm 0.01$ & $64.57 \pm 0.91$ & $1.98 \pm 0.01$ & $95.44 \pm 1.02$ \\
$\begin{array}{l}\text { Day 2 } \\
(48 \text { hours })\end{array}$ & $1.79 \pm 0.002$ & $61.67 \pm 0.32$ & $2.05 \pm 0.03$ & $111.50 \pm 1.07$ \\
$\begin{array}{l}\text { Day 3 } \\
\text { (72 hours })\end{array}$ & $1.80 \pm 0.04$ & $63.10 \pm 4.99$ & $2.03 \pm 0.02$ & $107.20 \pm 1.05$ \\
\hline
\end{tabular}

within the range of safe dosage showed improvements in cell viabilities with longer incubation period. The possible reasons for such observations could be the potential cell proliferation induction effects from the extracts or activation of cellular protective response that counteract the stress, for adaptation and survival. However, further studies are needed to support this conjecture. The data also revealed that the $\mathrm{IC}_{50}$ range of RBE of BJLN was lower than that for MR219.

Chemical analyses of total antioxidant compound contents indicated that the RBE of BJLN had significantly higher contents of antioxidants (total phenolic and total flavonoid compounds, total $\gamma$-oryzanol, and total vitamin $\mathrm{E}$ components) compared to MR219 (Figure 3). Therefore, the $\mathrm{RBE}$ of BJLN may require a lower concentration to achieve similar antioxidant activities as the MR219. These differences may account for the difference in their $\mathrm{IC}_{50}$.

Significant decrement in cell viability of H9c2(2-1) cardiomyocytes was reported when high doses of RBE were used, suggesting dose-dependent cytotoxicity effects of the RBEs. Several reports have highlighted cell cytotoxicity effects of polyphenols when high doses of the antioxidants were used $[29,30]$ in which they act as prooxidants that threaten survival and viability of cells. 

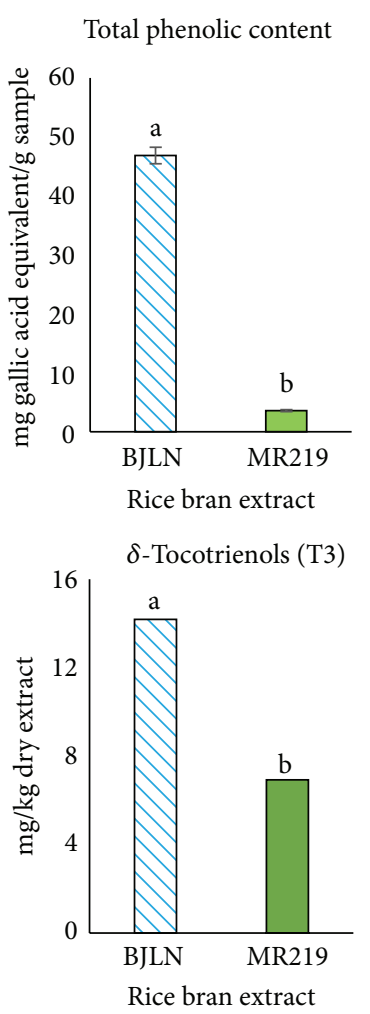

Total flavonoid content
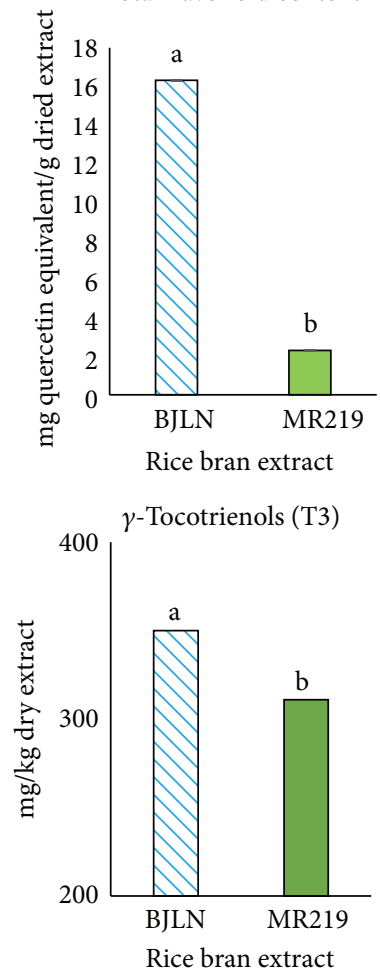

Total anthocyanin content
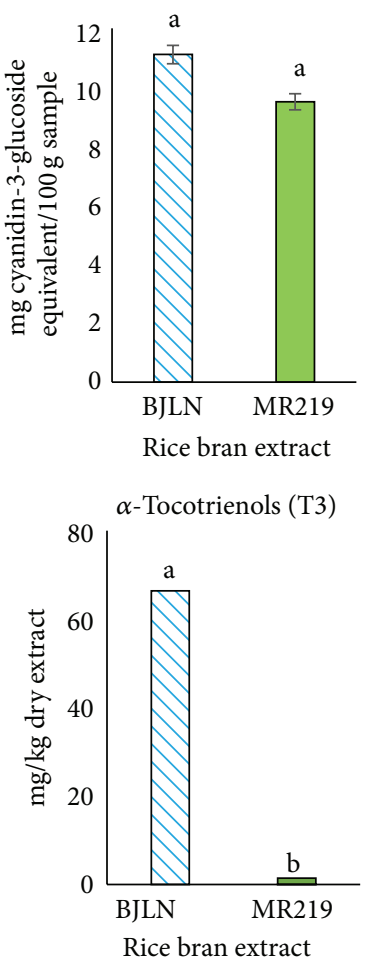

Total $\gamma$-oryzanol content
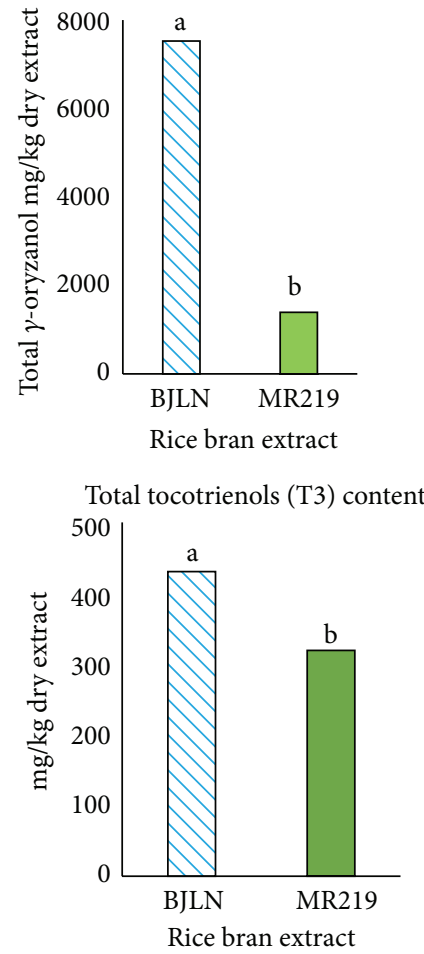

FIGURE 3: Total contents of selected bioactive compounds in the RBE. Different letter on a bar represents significant differences at $P \leq 0.05$ (Tukey's test).

3.2. Assessment of Cell Cytotoxicity Effects of Hydrogen Peroxide. H9c2(2-1) cardiomyocytes were induced with different concentrations of hydrogen peroxide $\left(\mathrm{H}_{2} \mathrm{O}_{2}\right)$ to identify the suitable range of working concentrations that do not induce cell death. Figure 4 shows the cell viability curve of H9c2(2-1) cells treated with different concentrations of $\mathrm{H}_{2} \mathrm{O}_{2}$. Data are presented in terms of relative cell viability versus log of extract dosage. A dose-dependent cytotoxicity effect was observed in cells treated with $\mathrm{H}_{2} \mathrm{O}_{2}$. The range of $\mathrm{H}_{2} \mathrm{O}_{2}$ concentrations between $15.63 \mu \mathrm{M}$ and $250 \mu \mathrm{M}$ did not decrease the viability of $\mathrm{H} 9 \mathrm{c} 2(2-1)$ cells. Therefore, $\mathrm{H}_{2} \mathrm{O}_{2}$ in this range was considered safe.

Cell viabilities were more than $87 \%$ after treatment with $\mathrm{H}_{2} \mathrm{O}_{2}$ within the above range. However, exceeding the concentration of $250 \mu \mathrm{M} \mathrm{H}_{2} \mathrm{O}_{2}$ caused a significant decrease in cell viability to less than $48 \%$. In addition, $\mathrm{IC}_{50}$ of $\mathrm{H}_{2} \mathrm{O}_{2}$ on $\mathrm{H} 9 \mathrm{c} 2(2-1)$ cells was detected at $572.10 \mu \mathrm{M}\left(\log \left[\mathrm{H}_{2} \mathrm{O}_{2}\right]=\right.$ 2.76).

Under normal cellular metabolic activities, low concentrations of $\mathrm{H}_{2} \mathrm{O}_{2}$ are produced as a by-product that is relatively harmless and beneficial to most cells [31]. Cells utilize $\mathrm{H}_{2} \mathrm{O}_{2}$ for processes such as oxidative biosynthesis and host defense. In addition, there are also evidences showing the potential of $\mathrm{H}_{2} \mathrm{O}_{2}$ as a signaling messenger in cellular signal transduction pathways [31]. However, overaccumulation of $\mathrm{H}_{2} \mathrm{O}_{2}$ can be deleterious, as it can lead to the onset of oxidative stress and subsequently oxidative stress mediated diseases over time [32].

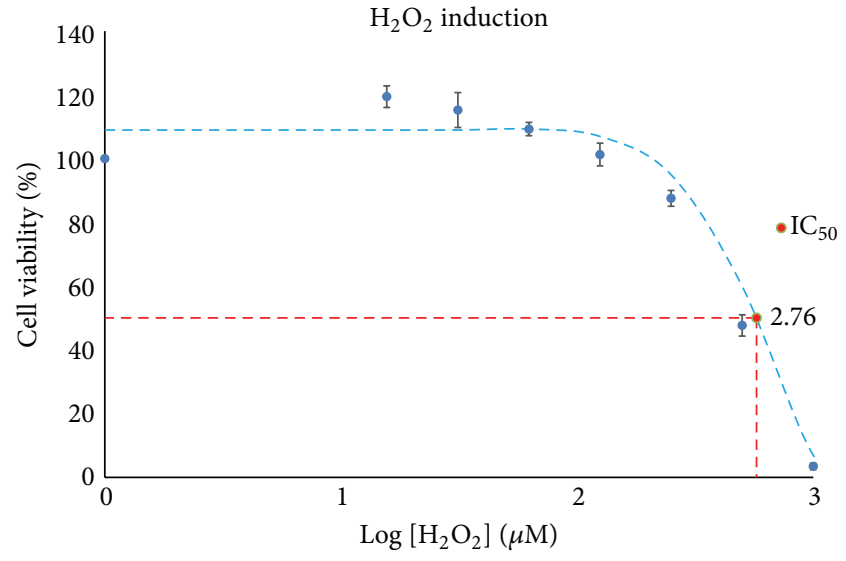

FIGURE 4: Cell viability curves of $\mathrm{H} 9 \mathrm{c} 2(2-1)$ cells treated with different concentrations of hydrogen peroxide $\left(\mathrm{H}_{2} \mathrm{O}_{2}\right)$. The insets showed the inhibition concentration $\left(\mathrm{IC}_{50}\right)$ of $\mathrm{H}_{2} \mathrm{O}_{2}$ on $\mathrm{H} 9 \mathrm{c} 2(2$ 1) cells determined via GraphPad Prism (GraphPad Software, Inc., USA). Best fit curve was drawn using Excel for visual purpose. Tabulated data are presented in Table A, in Supplementary Material available online at http://dx.doi.org/10.1155/2016/6943053.

Based on the results, H9c2(2-1) cells induced with low concentrations of $\mathrm{H}_{2} \mathrm{O}_{2}(15.63 \mu \mathrm{M}$ and $31.25 \mu \mathrm{M})$ showed proliferative effect. The cell viabilities were more than $100 \%$ in relation to the negative control. This observation suggests 


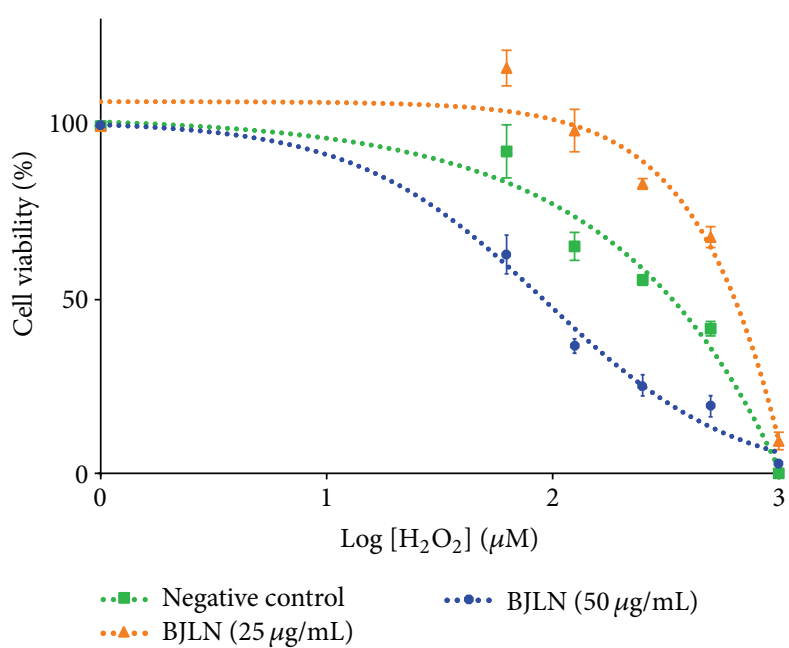

(a) $\mathrm{RBE}(\mathrm{BJLN})+\mathrm{H}_{2} \mathrm{O}_{2}$ induction

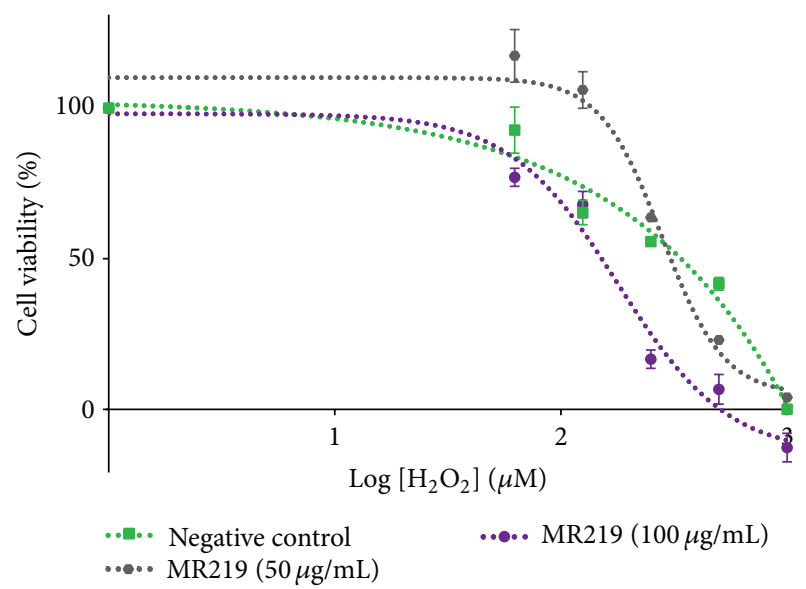

(b) $\mathrm{RBE}(\mathrm{MR} 219)+\mathrm{H}_{2} \mathrm{O}_{2}$ induction

FIGURE 5: Effects of $\mathrm{H}_{2} \mathrm{O}_{2}$ inductions on cell viabilities of $\mathrm{H} 9 \mathrm{c} 2(2-1)$ cardiomyocytes pretreated with different concentrations of (a) BJLN RBE $(25 \mu \mathrm{g} / \mathrm{mL}$ and $50 \mu \mathrm{g} / \mathrm{mL})$ and (b) MR219 RBE $(50 \mu \mathrm{g} / \mathrm{mL}$ and $100 \mu \mathrm{g} / \mathrm{mL})$.

the potential of low concentration of $\mathrm{H}_{2} \mathrm{O}_{2}$ in stimulating cell growth of $\mathrm{H} 9 \mathrm{c} 2(2-1)$ as low concentration of $\mathrm{H}_{2} \mathrm{O}_{2}$ has been reported to be capable of stimulating cell proliferation [33]. In addition, the present data are in agreement with the general response trend of proliferating mammalian cells to $\mathrm{H}_{2} \mathrm{O}_{2}$ [34-36]. It has been reported that low concentration of $\mathrm{H}_{2} \mathrm{O}_{2}$ in range of 3 to $15 \mu \mathrm{M}$ has the potential of inducing growth stimulation while the higher concentration range, 120 to $150 \mu \mathrm{M}$, can cause growth arrest temporarily. Growth arrest may occur permanently when cells are induced with $\mathrm{H}_{2} \mathrm{O}_{2}$ in the concentration range between $250 \mu \mathrm{M}$ and $400 \mu \mathrm{M}$ while concentration of $\mathrm{H}_{2} \mathrm{O}_{2}$ beyond $1000 \mu \mathrm{M}$ may induce cell necrosis [34-36]. Therefore, variation in cellular responses towards different concentrations of $\mathrm{H}_{2} \mathrm{O}_{2}$ could have potentially induced the dose-dependent cytotoxicity effect of $\mathrm{H}_{2} \mathrm{O}_{2}$ on $\mathrm{H} 9 \mathrm{c} 2(2-1)$ cells.

\subsection{Cytoprotective Effects of RBE on Oxidative Stress Induced} Cells. The potential of RBE to alleviate oxidative stress in $\mathrm{H} 9 \mathrm{c} 2(2-1)$ cells mediated by $\mathrm{H}_{2} \mathrm{O}_{2}$ was investigated by pretreating the cells with different concentrations of each BJLN $(25 \mu \mathrm{g} / \mathrm{mL}$ and $50 \mu \mathrm{g} / \mathrm{mL})$ and MR219 $(50 \mu \mathrm{g} / \mathrm{mL}$ and $100 \mu \mathrm{g} / \mathrm{mL}$ ) extract before subsequent induction with various concentrations of $\mathrm{H}_{2} \mathrm{O}_{2}$. The induction effects are shown in Figure 5 and Table 3. Dose-dependent cytoprotective effects against $\mathrm{H}_{2} \mathrm{O}_{2}$ induced cell cytotoxicity were observed in cells pretreated with RBE. The positive effects were more distinctive with lower concentrations of RBE (BJLN: $25 \mu \mathrm{g} / \mathrm{mL}$; MR219: $50 \mu \mathrm{g} / \mathrm{mL}$ ) with observable increments in $\mathrm{IC}_{50}$ of $\mathrm{H}_{2} \mathrm{O}_{2}$ (BJLN: $645.65 \mu \mathrm{M}$; MR219: $320.63 \mu \mathrm{M}$ ) (Table 4) when compared to negative control $(316.23 \mu \mathrm{M})$. When the two extracts were compared, BJLN $(25 \mu \mathrm{g} / \mathrm{mL})$ extract outran MR219 $(50 \mu \mathrm{g} / \mathrm{mL})$ extract in terms of efficacy with a significant increment in $\mathrm{IC}_{50}$ of $\mathrm{H}_{2} \mathrm{O}_{2}$ approximately twofold $(645.65 \mu \mathrm{M})$ versus $1.4 \%$ (in approximation) when compared to negative control $(316.23 \mu \mathrm{M})$. The differences in cytoprotective efficacies of both extracts could be attributed to the difference in their respective total antioxidant contents.

However, the higher concentrations of BJLN $(50 \mu \mathrm{g} / \mathrm{mL})$ and MR219 $(100 \mu \mathrm{g} / \mathrm{mL})$ extracts tested did not result in cellular cytoprotection towards $\mathrm{H}_{2} \mathrm{O}_{2}$ induced cell cytotoxicity. Significant decrements in $\mathrm{IC}_{50}$ values of $\mathrm{H}_{2} \mathrm{O}_{2}$ were found for cell pretreated with $50 \mu \mathrm{g} / \mathrm{mL} \mathrm{BJLN}(92.90 \mu \mathrm{M})$ and $100 \mu \mathrm{g} / \mathrm{mL}$ MR219 $(171.79 \mu \mathrm{M})$ extracts when compared to negative control $(316.23 \mu \mathrm{M})$ (Table 4$)$. The higher concentrations of BJLN and MR219 extracts selected were near the range of $\mathrm{IC}_{50}$ of both extracts $\left(\mathrm{IC}_{50}\right.$ of BJLN: $52.18 \mu \mathrm{g} / \mathrm{mL}$ to $73.09 \mu \mathrm{g} / \mathrm{mL} ; \mathrm{IC}_{50}$ of MR219: $95.44 \mu \mathrm{g} / \mathrm{mL}$ to $111.50 \mu \mathrm{g} / \mathrm{mL}$ ). It was deduced that $\mathrm{H} 9 \mathrm{c} 2(2-1)$ cells could have experienced cytotoxic stress from both high concentrations of RBE and $\mathrm{H}_{2} \mathrm{O}_{2}$, respectively. As overdoses of natural antioxidants have been reported to exhibit prooxidant-like characteristics that potentially threaten cell survival and viability [37-39], additional cytotoxic stress derived from $\mathrm{H}_{2} \mathrm{O}_{2}$ could have further decreased the viability of $\mathrm{H} 9 \mathrm{c} 2(2-1)$ after treatment with extract and $\mathrm{H}_{2} \mathrm{O}_{2}$, respectively.

Various chronic diseases such as cardiovascular diseases, cancer, and diabetes are closely associated with oxidative stress. Factors such as molecular targets, mechanism, and severity of oxidative stress define the consequence of oxidative stress injury on cells. This may further initiate signal transduction cascade reactions that lead to the onset and progression of chronic diseases [11, 40]. The present preliminary results have revealed the potential of RBE as a source of natural antioxidants to alleviate oxidative stress mediated cytotoxicity. Coupled with further carefully planned investigations, RBE could be considered for further application as nutraceuticals for protection against chronic diseases mediated by oxidative stress, such as cardiovascular diseases.

3.4. Determination of the Effects of Different Cellular Inductions on Activities of Cellular Endogenous Antioxidant Enzymes and Expression of Relevant Genes. The antioxidative 
TABLE 3: Cell viability of $\mathrm{H} 9 \mathrm{c} 2(2-1)$ after inductions with different concentrations of $\mathrm{H}_{2} \mathrm{O}_{2}$. Cells were pretreated with different concentrations of BJLN and MR219 RBE before $\mathrm{H}_{2} \mathrm{O}_{2}$ induction. Data represent mean \pm standard deviation of three technical replicates $(n=3)$. “*” on each column denotes significant differences at $P \leq 0.05$ as compared to negative control (nontreated cells).

\begin{tabular}{|c|c|c|c|c|c|c|}
\hline \multirow{2}{*}{$\begin{array}{l}\log \left[\mathrm{H}_{2} \mathrm{O}_{2}\right] \\
\mu \mathrm{M}\end{array}$} & \multirow{2}{*}{$\begin{array}{l}\mathrm{H}_{2} \mathrm{O}_{2} \\
(\mu \mathrm{M})\end{array}$} & \multicolumn{5}{|c|}{ Cell viability (\%) } \\
\hline & & $\begin{array}{c}\text { Negative control } \\
(\text { media }+1 \% \text { EtOH })\end{array}$ & $\begin{array}{c}\text { BJLN } \\
(25 \mu \mathrm{g} / \mathrm{mL})\end{array}$ & $\begin{array}{c}\text { BJLN } \\
(50 \mu \mathrm{g} / \mathrm{mL})\end{array}$ & $\begin{array}{c}\text { MR219 } \\
(50 \mu \mathrm{g} / \mathrm{mL})\end{array}$ & $\begin{array}{c}\text { MR219 } \\
(100 \mu \mathrm{g} / \mathrm{mL})\end{array}$ \\
\hline 1.80 & 62.5 & $92.61 \pm 7.62$ & $116.67 \pm 4.83^{*}$ & $62.80 \pm 5.55^{*}$ & $117.30 \pm 8.43$ & $76.93 \pm 8.30^{*}$ \\
\hline 2.10 & 125 & $65.31 \pm 3.75^{*}$ & $99.09 \pm 6.12$ & $36.95 \pm 2.09^{*}$ & $105.91 \pm 6.24$ & $67.93 \pm 2.96^{*}$ \\
\hline 2.40 & 250 & $55.70 \pm 1.27^{*}$ & $83.05 \pm 1.61^{*}$ & $25.04 \pm 3.22^{*}$ & $63.50 \pm 0.97^{*}$ & $16.86 \pm 2.88^{*}$ \\
\hline 2.70 & 500 & $41.65 \pm 2.20^{*}$ & $67.87 \pm 1.77^{*}$ & $19.62 \pm 2.90^{*}$ & $35.15 \pm 3.62^{*}$ & $6.56 \pm 4.99^{*}$ \\
\hline 3.00 & 1000 & $3.67 \pm 2.52^{*}$ & $9.55 \pm 2.48^{*}$ & $2.18 \pm 0.32^{*}$ & $4.15 \pm 0.32^{*}$ & $-12.66 \pm 4.56^{*}$ \\
\hline
\end{tabular}

TABLE 4: Average $\mathrm{IC}_{50}$ of $\mathrm{H}_{2} \mathrm{O}_{2}$ for $\mathrm{H} 9 \mathrm{c} 2(2-1)$ cells. The $\mathrm{IC}_{50}$ value was determined from respective cell viability curves (Figure 6) via GraphPad Prism (GraphPad Software, Inc., USA). Data represent mean \pm standard deviation of 3 technical replicates $(n=3)$. “*” denotes significant difference from negative control treated with media $+1 \%$ EtOH at $P \leq 0.05$. Graphical representations of data were depicted in Figure 5.

\begin{tabular}{lcc}
\hline & \multicolumn{2}{c}{ Average $\mathrm{IC}_{50}$ of $\mathrm{H}_{2} \mathrm{O}_{2}(\mu \mathrm{M})$} \\
& $\mathrm{Log}\left[\mathrm{H}_{2} \mathrm{O}_{2}\right]$ & $\mathrm{H}_{2} \mathrm{O}_{2}$ \\
\hline $\begin{array}{l}\text { Control sample } \\
\text { Negative control } \\
(\text { media }+1 \% \text { EtOH})\end{array}$ & $2.50 \pm 0.01$ & $316.23 \pm 1.02$ \\
$\mathrm{RBE}$ & & \\
$\mathrm{BJLN}(25 \mu \mathrm{g} / \mathrm{mL})$ & $2.81 \pm 0.04^{*}$ & $645.65 \pm 1.10^{*}$ \\
$\mathrm{BJLN}(50 \mu \mathrm{g} / \mathrm{mL})$ & $1.97 \pm 0.07^{*}$ & $92.90 \pm 1.17^{*}$ \\
MR219 $(50 \mu \mathrm{g} / \mathrm{mL})$ & $2.55 \pm 0.06^{*}$ & $320.63 \pm 1.14^{*}$ \\
MR219 $(100 \mu \mathrm{g} / \mathrm{mL})$ & $2.24 \pm 0.05^{*}$ & $171.79 \pm 1.13^{*}$ \\
\hline
\end{tabular}

protective mechanism of $\mathrm{RBE}$ was initially indistinct at the commencement of this study. It was hypothesized that RBE could exert its antioxidative properties through induction of endogenous cellular antioxidant enzymes. Endogenous cellular enzymatic antioxidants often refer to cellular antioxidant enzymes such as superoxide dismutase (SOD), catalase (CAT), and glutathione peroxidase (GPx) [41]. They are the first line of enzyme-based cellular defensive systems and each enzyme plays a different role in alleviation of oxidative injury [42].

As CAT is known as the main regulator for catalytic decomposition of $\mathrm{H}_{2} \mathrm{O}_{2}$ to harmless water molecules $\left(\mathrm{H}_{2} \mathrm{O}\right)$ and oxygen $\left(\mathrm{O}_{2}\right)$ [43], it was selected as the biomarker to test the above-mentioned hypothesis. The antioxidative protective effect of RBE was tested against the CAT enzyme, of which the effects of different inductions were assessed by studying changes in expression of the corresponding gene and total cellular activities of CAT on H9c2(2-1) cells subjected to different treatments as compared to those in untreated (control) cells.
3.4.1. Effects of RBE Inductions on Activities and Expression of CAT Gene. Two extract concentrations that did not induce cell cytotoxicity were selected to study their respective induction effects on gene activities and gene expression of CAT in induced H9c2(2-1) cardiomyocytes. The effects of treating $\mathrm{H} 9 \mathrm{c} 2(2-1)$ cells with $\mathrm{RBE}$ on the enzymatic activity and expression level of CAT are depicted in Figure 6. Induction with BJLN $(50 \mu \mathrm{g} / \mathrm{mL}$ ) and MR219 (50 and $100 \mu \mathrm{g} / \mathrm{mL}$ ) $\mathrm{RBE}$ appeared to have elevated the enzymatic activity of CAT, while no significant improvement was observed with $25 \mu \mathrm{g} / \mathrm{mL}$ of BJLN (Figure 6(a)). Higher concentrations of RBEs typically induced higher activities. In addition, significantly higher activities were observed with MR219 RBE compared to BJLN. Briefly, the activity had increased by $\sim 40 \%$ and $\sim 100 \%$ in relation to negative control with $50 \mu \mathrm{g} / \mathrm{mL}$ of BJLN RBE and $100 \mu \mathrm{g} / \mathrm{mL}$ of MR219 RBE, while $50 \mu \mathrm{g} / \mathrm{mL}$ of MR219 RBE only weakly elevated the activity ( 16\%). The CAT (catalase, Cat (Gene ID: 24248)) gene expression levels were also significantly upregulated with all concentrations of extracts (Figure $6(\mathrm{~b})$ ) in the range of $\sim 18 \%$ to $\sim 40 \%$. In addition, it was discovered that BJLN extracts expressed higher levels of CAT (relative to negative control) as compared to MR219 extracts. There was no significant difference in expression of CAT between the two different concentrations of each extract selected for this part of the study. The effects of RBEs on the enzymatic activity and gene expression of CAT may be attributed to their polyphenol contents, as these can generate prooxidants. This may cause oxidative stress and trigger cytoprotective mechanisms.

3.4.2. Effects of $\mathrm{H}_{2} \mathrm{O}_{2}$ Inductions on Activities and Expression of CAT. Effects of $\mathrm{H}_{2} \mathrm{O}_{2}$ inductions on the enzymatic activity and expression levels of CAT in H9c2(2-1) cells were depicted in Figure 7. H9c2(2-1) cells were incubated with three different concentrations of $\mathrm{H}_{2} \mathrm{O}_{2}$ for 24 hours. The results revealed that cellular induction with $250 \mu \mathrm{M}$ of $\mathrm{H}_{2} \mathrm{O}_{2}$ significantly increased the CAT activity by $\sim 20 \%$. Contrarily, there no significant difference in CAT activity was observed with $125 \mu \mathrm{M}$ and $500 \mu \mathrm{M}$ of $\mathrm{H}_{2} \mathrm{O}_{2}$, respectively (Figure 7(a)). Induction of $\mathrm{H} 9 \mathrm{c} 2(2-1)$ with different concentrations of $\mathrm{H}_{2} \mathrm{O}_{2}$ significantly elevated the expression levels of CAT (Figure $7(\mathrm{~b})$ ), $\sim 80 \%$ to $\sim 380 \%$ in comparison to negative control. These observations were concurrent with other reported studies [44-47]. 

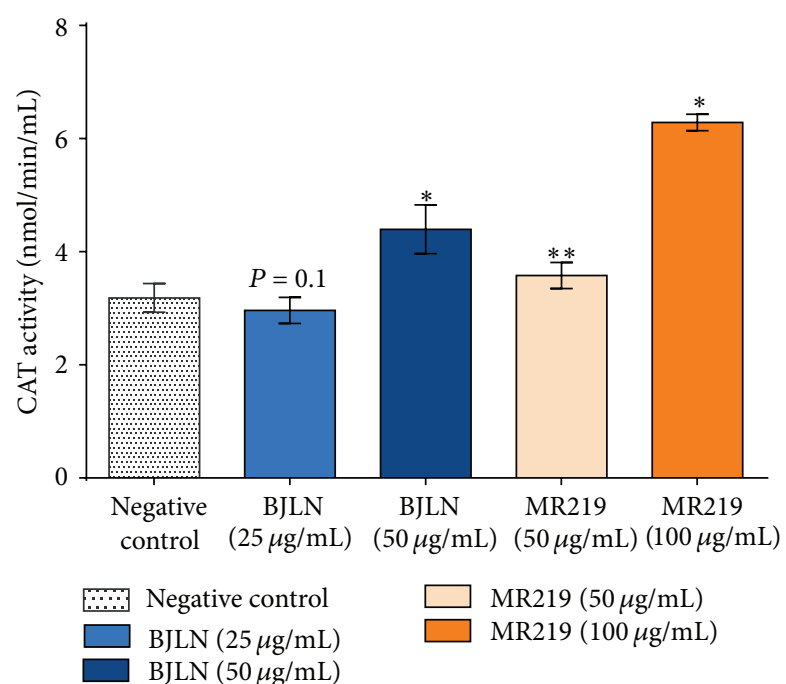

(a) Total CAT activity in H9c2(2-1) cells

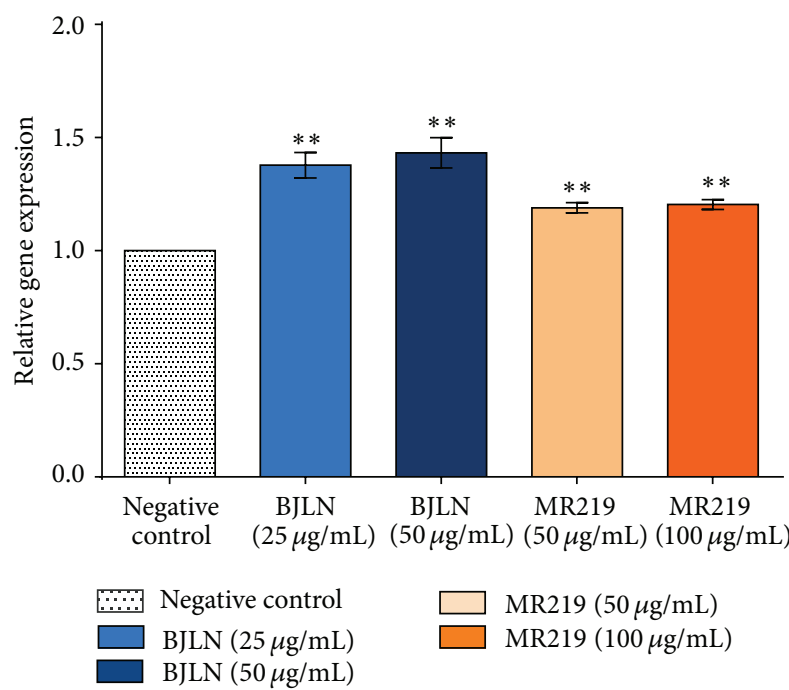

(b) Gene expression of CAT in H9c2(2-1) cells

FiguRE 6: Effects of RBE pretreatment of cells on CAT enzyme and gene expression. (a) Total CAT enzymatic activity; (b) CAT (catalase, Cat (Gene ID: 24248)) gene expression levels in H9c2(2-1) cells pretreated with different concentrations of RBE. Data represent mean \pm standard deviation of three technical replicates $(n=3)$. * Significantly different from negative control $(P \leq 0.05) ;{ }^{* *}$ significantly different from negative control $(P \leq 0.01)$.

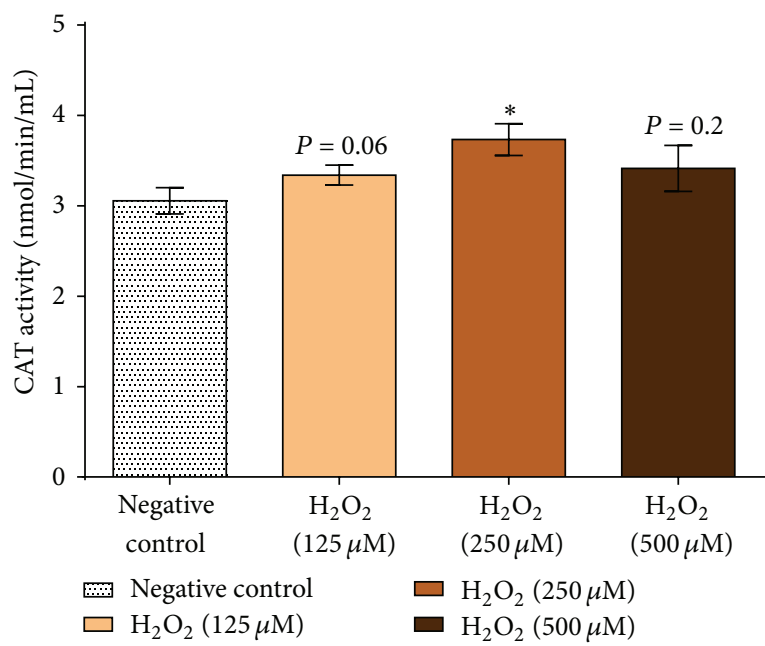

(a) Total CAT activity in $\mathrm{H} 9 \mathrm{c} 2(2-1)$ cells

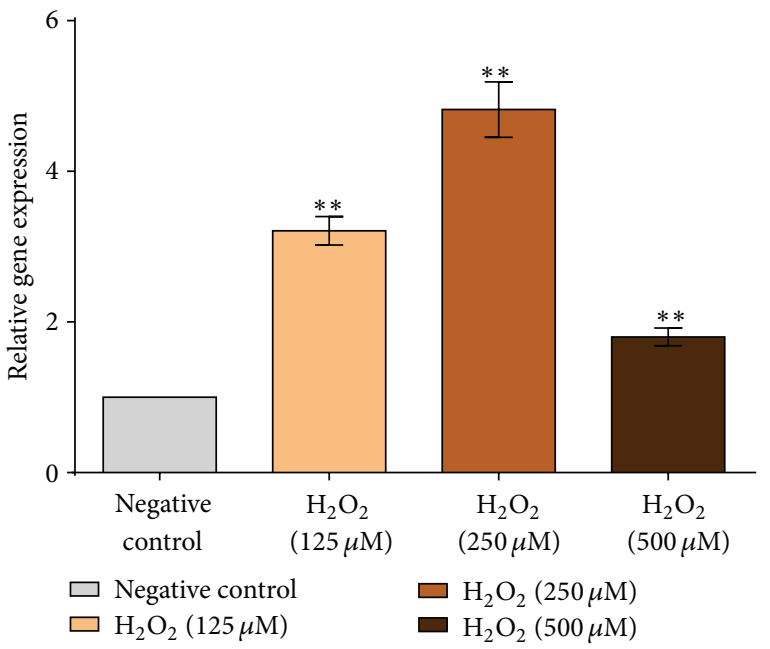

(b) Gene expression of CAT in H9c2(2-1) cells

Figure 7: (a) Total enzymatic activities and (b) gene expression levels of CAT after induction with different concentrations of $\mathrm{H}_{2} \mathrm{O}_{2}$. Data represent mean \pm standard deviation of three technical repetitions $(n=3)$. “*”: significantly different from negative control at $P \leq 0.05$; “**”: significantly different from negative control at $P \leq 0.01$.

Briefly, an increment in expression and activity of catalase represents the cellular defense mechanism against $\mathrm{H}_{2} \mathrm{O}_{2}$ mediated oxidative injuries. Among the three different concentrations of $\mathrm{H}_{2} \mathrm{O}_{2}$ studied $(125 \mu \mathrm{M}, 250 \mu \mathrm{M}$, and $500 \mu \mathrm{M})$, the highest upregulation was with $250 \mu \mathrm{M} \mathrm{H}_{2} \mathrm{O}_{2}$ (4.8-fold), followed by $125 \mu \mathrm{M} \mathrm{H}_{2} \mathrm{O}_{2}$ (3.2-fold) and $500 \mu \mathrm{M} \mathrm{H}_{2} \mathrm{O}_{2}$ (1.8fold).

CAT was actively involved in the detoxification of $\mathrm{H}_{2} \mathrm{O}_{2}$ produced from the enzymatic reaction of SOD and cellular metabolic activities [41]. It catalyses the conversion of $\mathrm{H}_{2} \mathrm{O}_{2}$ to $\mathrm{H}_{2} \mathrm{O}$ and $\mathrm{O}_{2}$ in a two-step reaction [48]. CAT naturally has a high Michaelis constant $(\mathrm{Km})$ for $\mathrm{H}_{2} \mathrm{O}_{2}$; hence it is capable of neutralizing high concentration of $\mathrm{H}_{2} \mathrm{O}_{2}$ [49]. In the presence of different concentrations of exogenous $\mathrm{H}_{2} \mathrm{O}_{2}$, activities and gene expression of CAT in H9c2(21) cardiomyocytes induced with different concentrations of $\mathrm{H}_{2} \mathrm{O}_{2}$ were significantly upregulated in a dose-dependent manner. An increase in activity and expression levels of CAT 


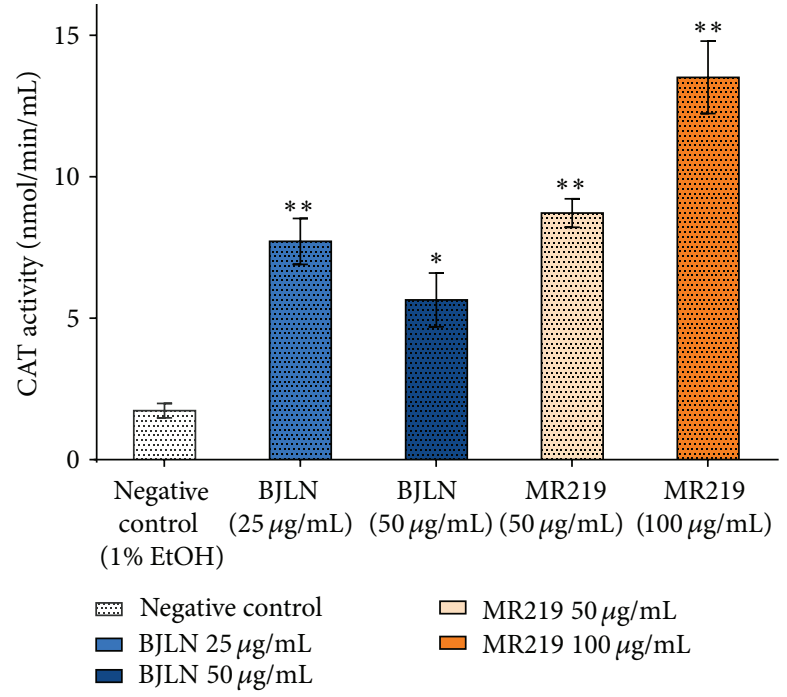

(a) Total CAT activity in $\mathrm{H} 9 \mathrm{c} 2(2-1)$ cells

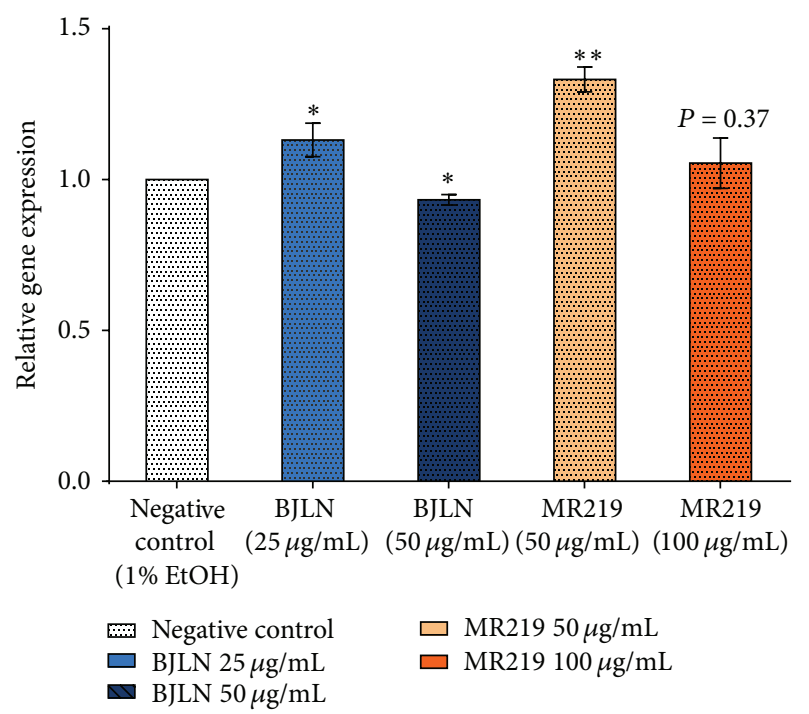

(b) Gene expression of CAT in H9c2(2-1) cells

FIGURE 8: (a) Total enzymatic activities and (b) gene expression levels of CAT in RBE pretreated H9c2(2-1) cells after induction with 125 $\mu \mathrm{M}$ of $\mathrm{H}_{2} \mathrm{O}_{2}$. Data represent mean \pm standard deviation of three technical repetitions $(n=3)$. “*”: significantly different from negative control $(P \leq 0.05)$; “**”: significantly different from negative control $(P \leq 0.01)$.

was reported with $125 \mu \mathrm{M}$ and $250 \mu \mathrm{M}$ of $\mathrm{H}_{2} \mathrm{O}_{2}$, respectively, and followed by a decrease in activity and gene expression of CAT when cells were induced with $500 \mu \mathrm{M} \mathrm{H}_{2} \mathrm{O}_{2}$.

3.4.3. Effects of $\mathrm{H}_{2} \mathrm{O}_{2}$ Inductions on Activities and Expression of CAT in Cells Pretreated with RBE. Figure 8 showed the effects of the treatment on enzymatic activities and gene expression of CAT. Briefly, CAT activities of cells pretreated with RBE were significantly increased (3-8-fold) after being induced with $125 \mu \mathrm{M}$ of $\mathrm{H}_{2} \mathrm{O}_{2}$ (Figure $8(\mathrm{a})$ ). Sample group pretreated with $100 \mu \mathrm{g} / \mathrm{mL}$ of MR219 extract reported the highest fold change ( $\sim$-fold) in CAT activity when compared to control group, followed by $50 \mu \mathrm{g} / \mathrm{mL}$ of MR219 extract ( $\sim 5$-fold), $25 \mu \mathrm{g} / \mathrm{mL}$ of BJLN extract ( $\sim 4.5$-fold), and $50 \mu \mathrm{g} / \mathrm{mL}$ of BJLN extract ( $\sim 3.3$-fold). With regard to the gene expression profiles of CAT, the lower concentrations of both BJLN $(25 \mu \mathrm{g} / \mathrm{mL})$ and MR219 $(50 \mu \mathrm{g} / \mathrm{mL})$ extracts significantly upregulated the expression levels of CAT by $13 \%$ and $33 \%$, respectively, in relation to negative control. A slight downregulation in expression of CAT $(\sim 7 \%)$ was observed with cells pretreated with $50 \mu \mathrm{g} / \mathrm{mL}$ of BJLN extract. No significant difference in expression of CAT was noted between negative control and $100 \mu \mathrm{g} / \mathrm{mL}$ of MR219 treated cells. It is of note that there was a lack of exact correlation between the enzymatic activity of CAT and its gene expression level. Such findings were also reported by Chiang et al. whose work was focusing on evaluating the activities of SOD, CAT, and GPx in HepG2 cells treated with rice extracts [50]. Similarly, it was reported that there was a lack of exact relationship between the enzymes' activities and their respective gene expression [50]. It was suggested that such discrepancy was possibly regulated posttranslationally [51].

Based on the above findings, induction of $\mathrm{H} 9 \mathrm{c} 2(2-1)$ cardiomyocytes with different concentrations of $\mathrm{RBE}$ and $\mathrm{H}_{2} \mathrm{O}_{2}$ revealed their distinctive effects in regulating the activities of CAT. The present data revealed that pretreating $\mathrm{H} 9 \mathrm{c} 2(2-$ 1) cells with RBE before $\mathrm{H}_{2} \mathrm{O}_{2}$ induction (with $125 \mu \mathrm{M} \mathrm{H}_{2} \mathrm{O}_{2}$ ) resulted in significant improvement in the enzymatic activity of CAT. It is proposed that RBE could have protected H9c2(21) cells from oxidative injuries mediated by $\mathrm{H}_{2} \mathrm{O}_{2}$ via upregulation of CAT activity. However, other mechanisms involved in antioxidative properties of RBE against oxidative assault mediated by $\mathrm{H}_{2} \mathrm{O}_{2}$ remain to be further elucidated. Although present findings showed promising regulatory effect of RBE in the enzymatic activity of CAT, extended investigation on other additional biomarkers for intracellular ROS levels, apoptotic or necrotic cell death, or cell signaling pathways is suggested for further studies. The latter will offer deeper insight into the protective mechanism of RBE against $\mathrm{H}_{2} \mathrm{O}_{2}$ mediated cell cytotoxicity.

\section{Conclusion}

In the present study, the antioxidant activities of RBE derived from Sarawak local rice variety (BJLN) and a commercial rice variety (MR219) have been studied via in vitro cell-based assays. The results have demonstrated the potential of RBE as a source of naturally derived antioxidants to alleviate oxidative stress mediated cytotoxicity. With further investigations, RBE could be considered for application as a nutraceutical for protection against chronic diseases mediated by oxidative stress.

\section{Competing Interests}

The authors declare that they have no competing interests. 


\section{Acknowledgments}

This work was supported by Melbourne-Sarawak Research Collaboration Scheme Grant (MSRCS 2013) and Strategic Research Grant (StraRG 2-5607). The authors would like to acknowledge the assistance from Dr. Lim Sheau Chin (Universiti Sains Malaysia) and Dr. Paul Matthew Neilsen (Swinburne University of Technology Sarawak Campus, Malaysia) in providing technical advice. The authors would also like to acknowledge the support from staff, laboratory technicians, and postgraduates that have contributed to this study by providing invaluable assistance in lab and instrumental related matters. Permission has been granted by Sarawak Biodiversity Centre (SBC), Malaysia, for access to the collection and research on the selected Sarawak local rice varieties (Research Agreement no. SBC-RA-0093-HSS).

\section{References}

[1] M. S. Islam, N. Matsuki, R. Nagasaka et al., "Rice bran antioxidants in health and wellness," in Wheat and Rice in Disease Prevention and Health, R. R. W. R. P. Zibadi, Ed., vol. 34, chapter 34, pp. 443-451, Academic Press, San Diego, Calif, USA, 2014.

[2] T. Tsuda, F. Horio, Y. Kato, and T. Osawa, "Cyanidin 3-O- $\beta$ $\mathrm{D}$-glucoside attenuates the hepatic ischemia-reperfusion injury through a decrease in the neutrophil chemoattractant production in rats," Journal of Nutritional Science and Vitaminology, vol. 48, no. 2, pp. 134-141, 2002.

[3] M. Mukhopadhyay, "Natural antioxidants," in Natural Extracts Using Supercritical Carbon Dioxide, pp. 225-248, CRC Press, 2000.

[4] C. Aedín, P. José, and H. Peter, "Bioavailability of isoflavones in humans," in Flavonoids and Related Compounds, CRC Press, 2012.

[5] M. M. Anne and T. Barrie, "Tocotrienols in cardiometabolic diseases," in Tocotrienols, pp. 257-273, CRC Press, 2008.

[6] L. Biasutto, A. Mattarei, and M. Zoratti, "Resveratrol and health: the starting point," ChemBioChem, vol. 13, no. 9, pp. 1256-1259, 2012.

[7] C. G. Fraga and P. I. Oteiza, "Interactions of flavan-3-ols within cellular signaling pathways," in Flavonoids and Related Compounds, A. Crozier, Ed., chapter 12, CRC Press, New York, NY, USA, 2012.

[8] P. N. Chang, W. N. Yap, D. T. Wing Lee, M. T. Ling, Y. C. Wong, and Y. L. Yap, "Evidence of $\gamma$-tocotrienol as an apoptosis-inducing, invasion-suppressing, and chemotherapy drug-sensitizing agent in human melanoma cells," Nutrition and Cancer, vol. 61, no. 3, pp. 357-366, 2009.

[9] M. Urpi-Sarda, J. Rothwell, C. Morand, and C. Manach, "Bioavailability of flavanones," in Flavonoids and Related Compounds: Bioavailability and Function, J. P. E. Spencer and A. Crozier, Eds., CRC Press, New York, NY, USA, 2012.

[10] T. M. de Kok, S. G. Van Breda, and M. M. Manson, "Mechanisms of combined action of different chemopreventive dietary compounds: a review," European Journal of Nutrition, vol. 47, supplement 2, pp. 51-59, 2008.

[11] A. S. Magalhães, B. M. Silva, J. A. Pereira, P. B. Andrade, P. Valentão, and M. Carvalho, "Protective effect of quince (Cydonia oblonga Miller) fruit against oxidative hemolysis of human erythrocytes," Food and Chemical Toxicology, vol. 47, no. 6, pp. 1372-1377, 2009.
[12] V. Van Hoed, G. Depaemelaere, J. V. Ayala, P. Santiwattana, R. Verhé, and W. De Greyt, "Influence of chemical refining on the major and minor components of rice brain oil," Journal of the American Oil Chemists' Society, vol. 83, no. 4, pp. 315-321, 2006.

[13] R. Schramm, A. Abadie, N. Hua, Z. Xu, and M. Lima, "Fractionation of the rice bran layer and quantification of vitamin E, oryzanol, protein, and rice bran saccharide," Journal of Biological Engineering, vol. 1, article 9, 2007.

[14] M. S. Swaminathan and S. A. Rao, "Rice for sustainable food and nutritions security," in Rice Improvement in the Genomics Era, pp. 375-415, CRC Press, New York, NY, USA, 2008.

[15] R. P. Singh and A. Chakraverty, "Rice bran," in Postharvest Technology and Food Process Engineering, CRC Press, New York, NY, USA, 2014.

[16] T. S. Kahion, "Rice bran: production, composition, functionality and food applications, physiological benefits," in Fiber Ingredients: Food Applications and Health Benefits, S. S. Cho and P. Samuel, Eds., pp. 305-321, CRC Press, New York, NY, USA, 2009.

[17] T. A. Wilson, H. M. Idreis, C. M. Taylor, and R. J. Nicolosi, "Whole fat rice bran reduces the development of early aortic atherosclerosis in hypercholesterolemic hamsters compared with wheat bran," Nutrition Research, vol. 22, no. 11, pp. 13191332, 2002.

[18] L. M. Ausman, N. Rong, and R. J. Nicolosi, "Hypocholesterolemic effect of physically refined rice bran oil: studies of cholesterol metabolism and early atherosclerosis in hypercholesterolemic hamsters," The Journal of Nutritional Biochemistry, vol. 16, no. 9, pp. 521-529, 2005.

[19] M. L. Justo, M. Candiracci, A. P. Dantas et al., "Rice bran enzymatic extract restores endothelial function and vascular contractility in obese rats by reducing vascular inflammation and oxidative stress," Journal of Nutritional Biochemistry, vol. 24, no. 8, pp. 1453-1461, 2013.

[20] M. H. Bang, T. Van Riep, N. T. Thinh et al., "Arabinoxylan rice bran (MGN-3) enhances the effects of interventional therapies for the treatment of hepatocellular carcinoma: a three-year randomized clinical trial," Anticancer Research, vol. 30, no. 12, pp. 5145-5152, 2010.

[21] A. J. Henderson, C. A. Ollila, A. Kumar et al., "Chemopreventive properties of dietary rice bran: current status and future prospects," Advances in Nutrition, vol. 3, no. 5, pp. 643-653, 2012.

[22] J. S. L. De Munter, F. B. Hu, D. Spiegelman, M. Franz, and R. M. Van Dam, "Whole grain, bran, and germ intake and risk of type 2 diabetes: a prospective cohort study and systematic review," PLoS Medicine, vol. 4, no. 8, article e261, 2007.

[23] M. M. Most, R. Tulley, S. Morales, and M. Lefevre, "Rice bran oil, not fiber, lowers cholesterol in humans," American Journal of Clinical Nutrition, vol. 81, no. 1, pp. 64-68, 2005.

[24] E. T. Champagne, D. F. Wood, B. O. Juliano, and D. B. Bechtel, "Chapter 4: the rice grain and its gross composition," in RICE: Chemistry and Technology, pp. 77-107, American Association of Cereal Chemists, 2004.

[25] E. C. Borresen and E. P. Ryan, "Chapter 22: rice bran: a food ingredient with global public health opportunities," in Wheat and Rice in Disease Prevention and Health, R. R. W. R. P. Zibadi, Ed., pp. 301-310, Academic Press, San Diego, Calif, USA, 2014.

[26] P. Wang, S. M. Henning, and D. Heber, "Limitations of MTT and MTS-based assays for measurement of antiproliferative activity of green tea polyphenols," PLoS ONE, vol. 5, no. 4, Article ID e10202, 2010. 
[27] ISO, "Biological evaluation of medical devices-part 5: tests for in vitro cytotoxicity," ISO 10993-5, International Organization for Standardization, Geneva, Switzerland, 2009.

[28] J. L. Sebaugh, "Guidelines for accurate EC50/IC50 estimation," Pharmaceutical Statistics, vol. 10, no. 2, pp. 128-134, 2011.

[29] H. M. Awad, M. G. Boersma, S. Boeren, P. J. Van Bladeren, J. Vervoort, and I. M. C. M. Rietjens, "Structure-activity study on the quinone/quinone methide chemistry of flavonoids," Chemical Research in Toxicology, vol. 14, no. 4, pp. 398-408, 2001.

[30] J. D. Lambert and R. J. Elias, "The antioxidant and pro-oxidant activities of green tea polyphenols: a role in cancer prevention," Archives of Biochemistry and Biophysics, vol. 501, no. 1, pp. 6572, 2010.

[31] J. R. Stone and S. Yang, "Hydrogen peroxide: a signaling messenger," Antioxidants and Redox Signaling, vol. 8, no. 3-4, pp. 243-270, 2006.

[32] G. Nindl, N. R. Peterson, E. F. Hughes, L. R. Waite, and M. T. Johnson, "Effect of hydrogen peroxide on proliferation, apoptosis and interleukin-2 production of Jurkat T cells," Biomedical Sciences Instrumentation, vol. 40, pp. 123-128, 2004.

[33] R. H. Burdo and C. Rice-Evans, "Free radicals and the regulation of mammalian cell proliferation," Free Radical Research, vol. 6, no. 6, pp. 345-358, 1989.

[34] A. G. Wiese, R. E. Pacifici, and K. J. A. Davies, "Transient adaptation to oxidative stress in mammalian cells," Archives of Biochemistry and Biophysics, vol. 318, no. 1, pp. 231-240, 1995.

[35] H. Babich, H. L. Zuckerbraun, B. J. Wurzburger, Y. L. Rubin, E. Borenfreund, and L. Blau, "Benzoyl peroxide cytotoxicity evaluated in vitro with the human keratinocyte cell line, RHEK1," Toxicology, vol. 106, no. 1-3, pp. 187-196, 1996.

[36] K. J. A. Davies, “The broad spectrum of responses to oxidants in proliferating cells: a new paradigm for oxidative stress," IUBMB Life, vol. 48, no. 1, pp. 41-47, 1999.

[37] W. Wätjen, G. Michels, B. Steffan et al., "Low concentrations of flavonoids are protective in rat H4IIE cells whereas high concentrations cause DNA damage and apoptosis," Journal of Nutrition, vol. 135, no. 3, pp. 525-531, 2005.

[38] S. Azam, N. Hadi, N. U. Khan, and S. M. Hadi, "Prooxidant property of green tea polyphenols epicatechin and epigallocatechin-3-gallate: implications for anticancer properties," Toxicology in Vitro, vol. 18, no. 5, pp. 555-561, 2004.

[39] E. A. Decker, "Phenolics: prooxidants or antioxidants?" Nutrition Reviews, vol. 55, no. 11, part 1, pp. 396-398, 1997.

[40] O. I. Aruoma, "Free radicals, oxidative stress, and antioxidants in human health and disease," Journal of the American Oil Chemists' Society, vol. 75, no. 2, pp. 199-212, 1998.

[41] L. A. Pham-Huy, H. He, and C. Pham-Huy, "Free radicals, antioxidants in disease and health," International Journal of Biomedical Science, vol. 4, no. 2, pp. 89-96, 2008.

[42] R. Rodrigo, M. Libuy, F. Feliú, and D. Hasson, "Oxidative stressrelated biomarkers in essential hypertension and ischemiareperfusion myocardial damage," Disease Markers, vol. 35, no. 6, pp. 773-790, 2013.

[43] B. K. Tiwari, K. B. Pandey, A. B. Abidi, and S. I. Rizvi, "Markers of oxidative stress during diabetes mellitus," Journal of Biomarkers, vol. 2013, Article ID 378790, 8 pages, 2013.

[44] O. Meilhac, M. Zhou, N. Santanara, and S. Parthasarathy, "Lipid peroxides induce expression of catalase in cultured vascular cells," Journal of Lipid Research, vol. 41, no. 8, pp. 1205-1213, 2000 .
[45] A. C. Kotze, "Catalase induction protects Haemonchus contortus against hydrogen peroxide in vitro," International Journal for Parasitology, vol. 33, no. 4, pp. 393-400, 2003.

[46] S. Dieterich, U. Bieligk, K. Beulich, G. Hasenfuss, and J. Prestle, "Gene expression of antioxidative enzymes in the human heart: increased expression of catalase in the end-stage failing heart," Circulation, vol. 101, no. 1, pp. 33-39, 2000.

[47] A. B. Carter, L. A. Tephly, S. Venkataraman et al., "High levels of catalase and glutathione peroxidase activity dampen $\mathrm{H}_{2} \mathrm{O}_{2}$ signaling in human alveolar macrophages," American Journal of Respiratory Cell and Molecular Biology, vol. 31, no. 1, pp. 43-53, 2004.

[48] D. H. Kang and S. W. Kang, "Targeting cellular antioxidant enzymes for treating atherosclerotic vascular disease," Biomolecules \& Therapeutics, vol. 21, no. 2, pp. 89-96, 2013.

[49] R. Kohen and A. Nyska, "Oxidation of biological systems: oxidative stress phenomena, antioxidants, redox reactions, and methods for their quantification," Toxicologic Pathology, vol. 30, no. 6, pp. 620-650, 2002.

[50] A.-N. Chiang, H.-L. Wu, H.-I. Yeh, C.-S. Chu, H.-C. Lin, and W.-C. Lee, "Antioxidant effects of black rice extract through the induction of superoxide dismutase and catalase activities," Lipids, vol. 41, no. 8, pp. 797-803, 2006.

[51] M. Chaudhari, R. Jayaraj, S. R. Santhosh, and P. V. Lakshmana Rao, "Oxidative damage and gene expression profile of antioxidant enzymes after T-2 toxin exposure in mice," Journal of Biochemical and Molecular Toxicology, vol. 23, no. 3, pp. 212221, 2009. 


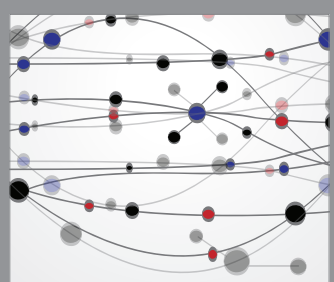

The Scientific World Journal
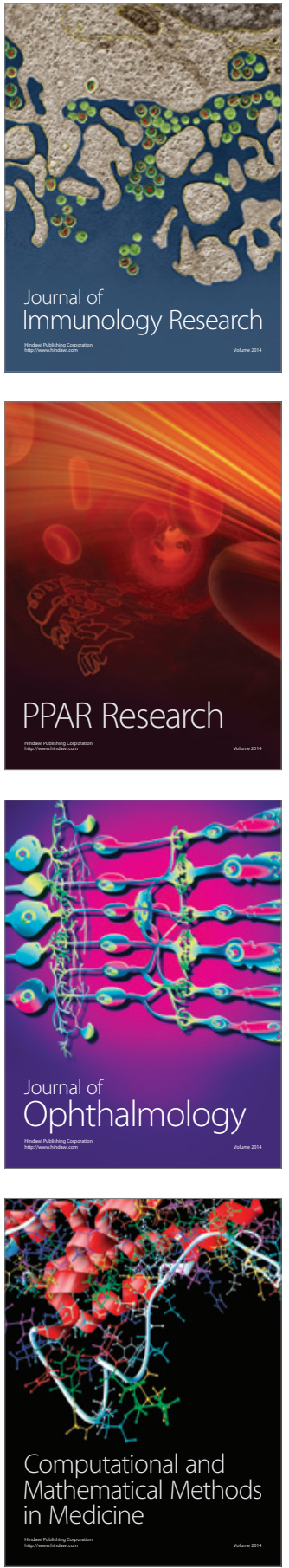

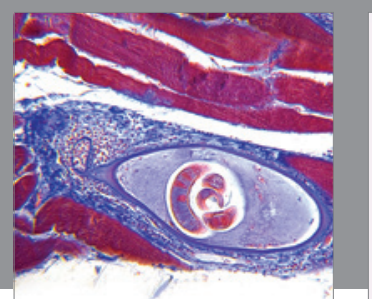

Gastroenterology Research and Practice

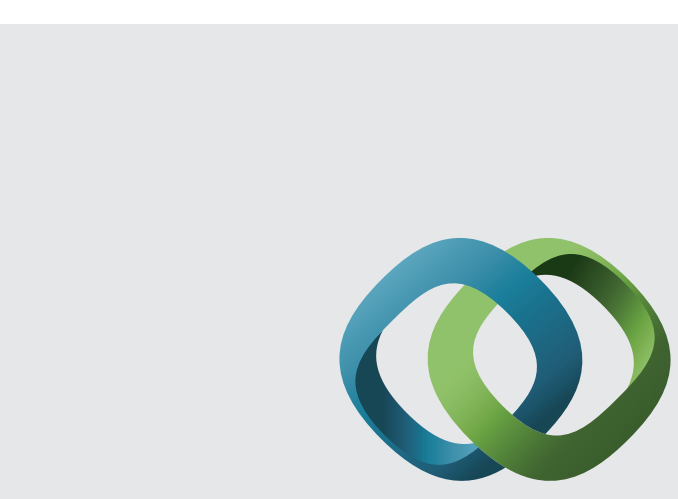

\section{Hindawi}

Submit your manuscripts at

http://www.hindawi.com
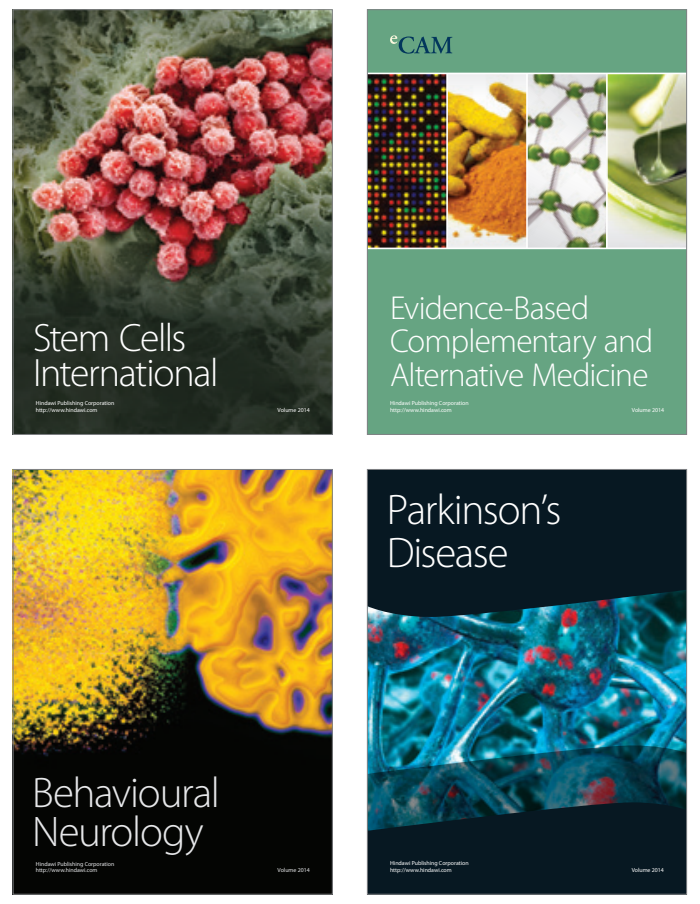
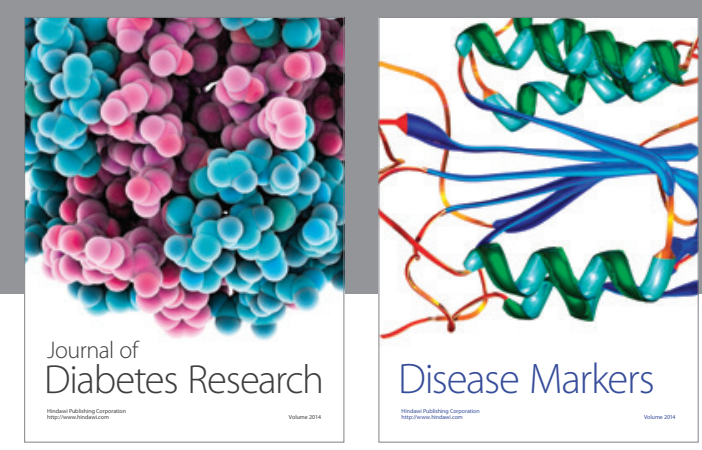

Disease Markers
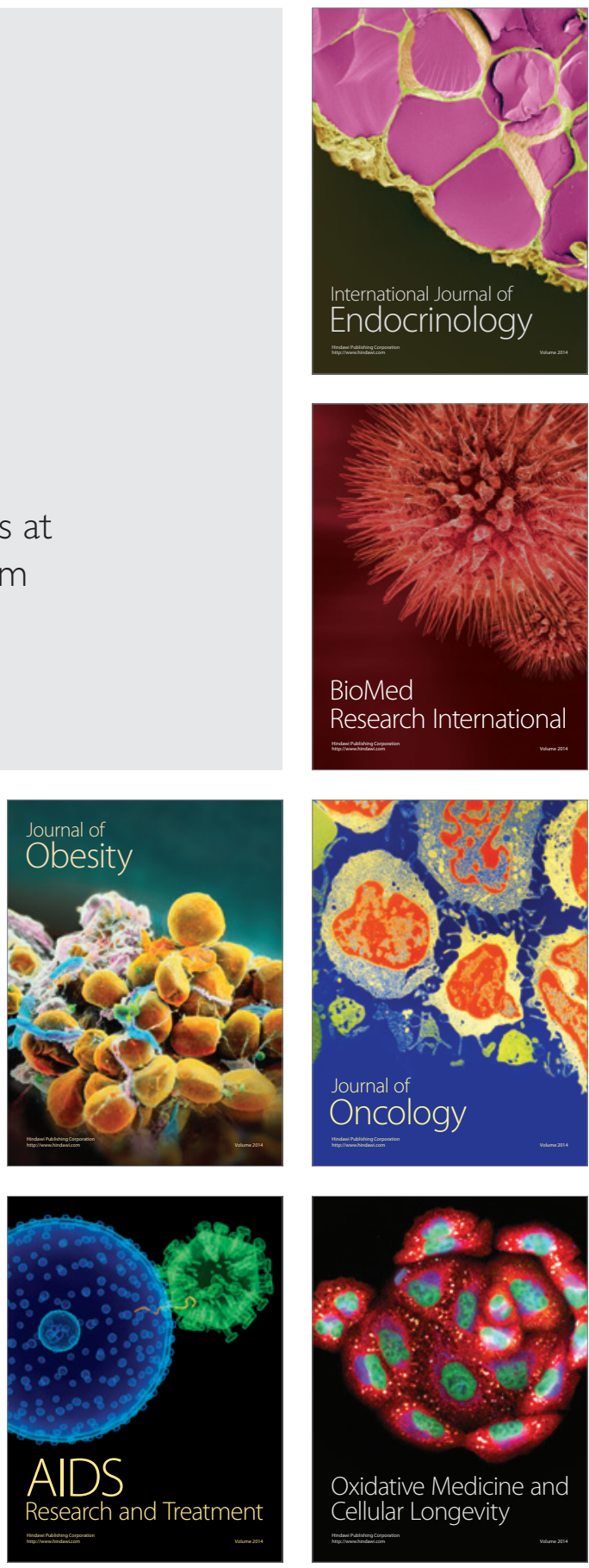